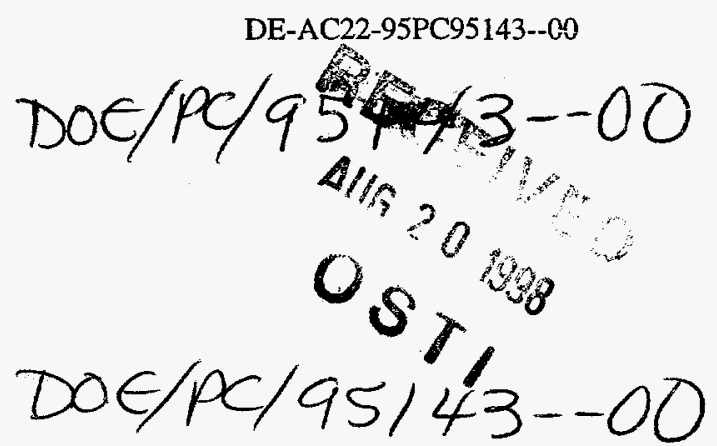

\title{
Engineering Development of Coal-Fired High-Performance Power Systems
}

\author{
Progress Report \\ April 1 - June 30, 1996
}

Work Performed Under Contract No.: DE-AC22-95PC95143

For

U.S. Department of Energy

Office of Fossil Energy

Federal Energy Technology Center

P.O. Box 880

Morgantown, West Virginia 26507-0880

By

Foster Wheeler Development Corporation

12 Peach Tree Hill Road

Livingston, New Jersey 07039

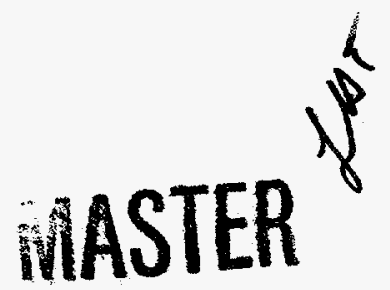




\section{Disclaimer}

This report was prepared as an account of work sponsored by an agency of the United States Government. Neither the United States Government nor any agency thereof, nor any of their employees, makes any warranty, express or implied, or assumes any legal liability or responsibility for the accuracy, completeness, or usefulness of any information, apparatus, product, or process disclosed, or represents that its use would not infringe privately owed rights. Reference herein to any specific commercial product, process, or service by trade name, trademark, manufacturer, or otherwise does not necessarily constitute or imply its endorsement, recommendation, or favoring by the United States Government or any agency thereof. The views and opinions of authors expressed herein do not necessarily state or reflect those of the United States Government or any agency thereof. 


\section{DISCLAIMER}

\section{Portions of this document may be illegible in electronic image products. Images are produced from the best available original document.}




\section{TABLE OF CONTENTS}

PAGE NO.

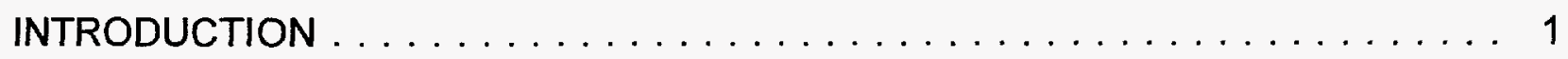

TECHNICAL PROGRESS $\ldots \ldots \ldots \ldots \ldots \ldots \ldots \ldots \ldots$

Task 1 - Project Planning and Management . . . . . . . . . . . . . 3

Modifying the Commercial Design Operating Parameters . . . . . . . 5

New Base Balance . . . . . . . . . . . . . . . . . . . . . . 8

Possible Bottoming Cycle Modifications $\ldots \ldots \ldots \ldots \ldots \ldots$

Task 2 - Engineering Research and Development . . . . . . . . . . . 19

Subtask 2.2 - Restrictive Pipe Discharge (RPD) System Cold Model . . . . 19

Task 3 - Subsystem Test Unit Design . . . . . . . . . . . . . . . . . 19

Subtask 3.1 - Pyrolyzer/Char Transport Test Design . . . . . . . . . 19

General Status ...................... 19

Task Matrix . . . . . . . . . . . . . . . . . . . . . 20

Data Acquisition . . . . . . . . . . . . . . . 20

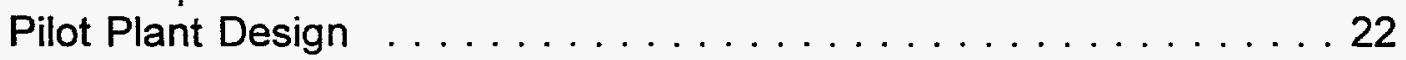

Subtask 3.2 - Char Combustion System Test Design . . . . . . . . . 25

Subtask 3.3 - Integrating System Test Design (IST) . . . . . . . . 25

Task 4 - Subsystem Test Unit Construction . . . . . . . . . . . . 27

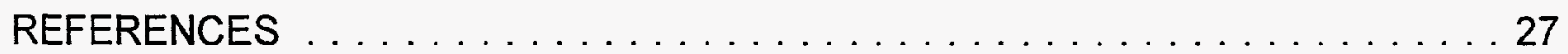




\section{LIST OF FIGURES}

Figure No.

PAGE NO.

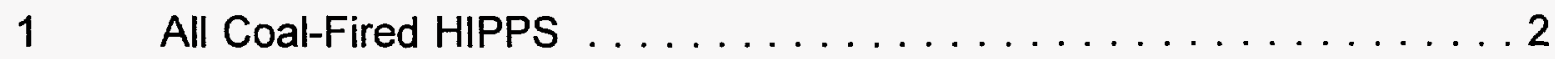

$2 \quad 35$ Percent Natural Gas HIPPS $\ldots \ldots \ldots \ldots \ldots \ldots \ldots \ldots$

3 Relationship of Steam to Pyrolyzer and Air Heater

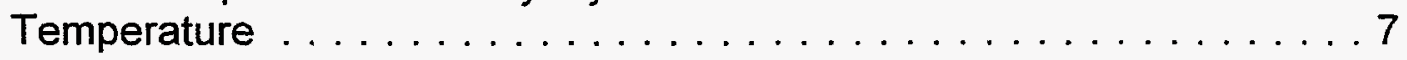

$4 \quad$ Relationship of GT Inlet Temperature and Steam Flow to

Pyrolyzer on Plant Efficiency . . . . . . . . . . . . . . 7

$5 \quad$ HIPPS Commercial Plant Process Flow Diagram . . . . . . . . 10

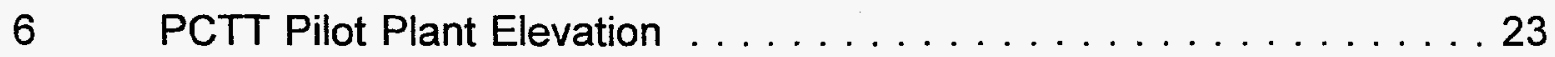

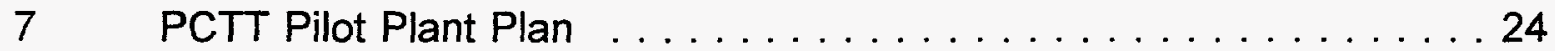

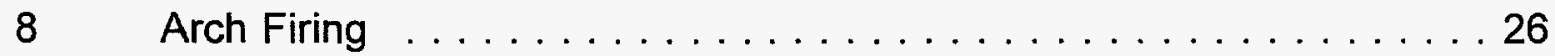




\section{LIST OF TABLES}

Table No.

PAGE NO.

1

Performance Summary $\ldots \ldots \ldots \ldots \ldots \ldots \ldots \ldots \ldots$

2 Major Process Streams - All Coal Commercial Case . . . . . . . . 12

3 Summary of Indirect Heating Results $\ldots \ldots \ldots \ldots \ldots \ldots$

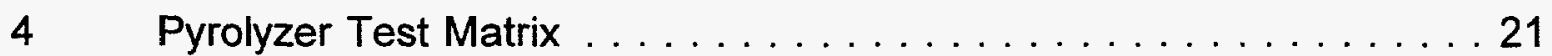




\section{INTRODUCTION}

In Phase 1 of the project, a conceptual design of a coal-fired, high-performance power system was developed, and small-scale R\&D was done in critical areas of the design. The current phase of the project includes development through the pilot plant stage and design of a prototype plant that would be built in Phase 3 .

Foster Wheeler Development Corporation (FWDC) is leading a team of companies in this effort. These companies are:

- Foster Wheeler Energy Corporation (FWEC)

- AlliedSignal Aerospace Equipment Systems

- Bechtel Corporation

- University of Tennessee Space Institute (UTSI)

- Westinghouse Electric Corporation

The power-generating system being developed in this project will be an improvement over current coal-fired systems. Goals have been identified that relate to the efficiency, emissions, costs, and general operation of the system. These goals are:

- Total station efficiency of at least 47 percent on a HHV basis.

- Emissions:

$\begin{array}{ll}\text { NOx } & <0.06 \mathrm{lb} / \mathrm{MM} \mathrm{Btu} \\ \text { SOx } & <0.06 \mathrm{lb} / \mathrm{MM} \mathrm{Btu} \\ \text { Particulates } & <0.003 \mathrm{lb} / \mathrm{MM} \mathrm{Btu}\end{array}$

- All solid wastes must be benign with regard to disposal.

- Over 95 percent of the total heat input is ultimately from coal, with initial systems capable of using coal for at least 65 percent of the heat input.

- Ten-percent lower cost of electricity (COE) relative to a modern coal-fired plant conforming to NSPS.

The base case arrangement of the HIPPS cycle is shown in Figure 1. It is a combined-cycle plant. This arrangement is referred to as the All Coal HIPPS because it does not require any other fuels for normal operation. A fluidized bed, air-blown pyrolyzer converts coal into fuel gas and char. The char is fired in a high-temperature advanced furnace (HITAF) which heats both air for a gas turbine and steam for a steam turbine. The air is heated up to $760^{\circ} \mathrm{C}\left(1400^{\circ} \mathrm{F}\right)$ in the HITAF, and the tube banks for heating the air are constructed of alloy tubes. The fuel gas from the pyrolyzer goes to a topping combustor where it is used to raise the air entering the gas turbine to $1288^{\circ} \mathrm{C}\left(2350^{\circ} \mathrm{F}\right)$. In addition to the HITAF, steam duty is achieved with a heat-recovery steam generator (HRSG) in the gas turbine exhaust stream and economizers in the HITAF flue gas exhaust stream. 


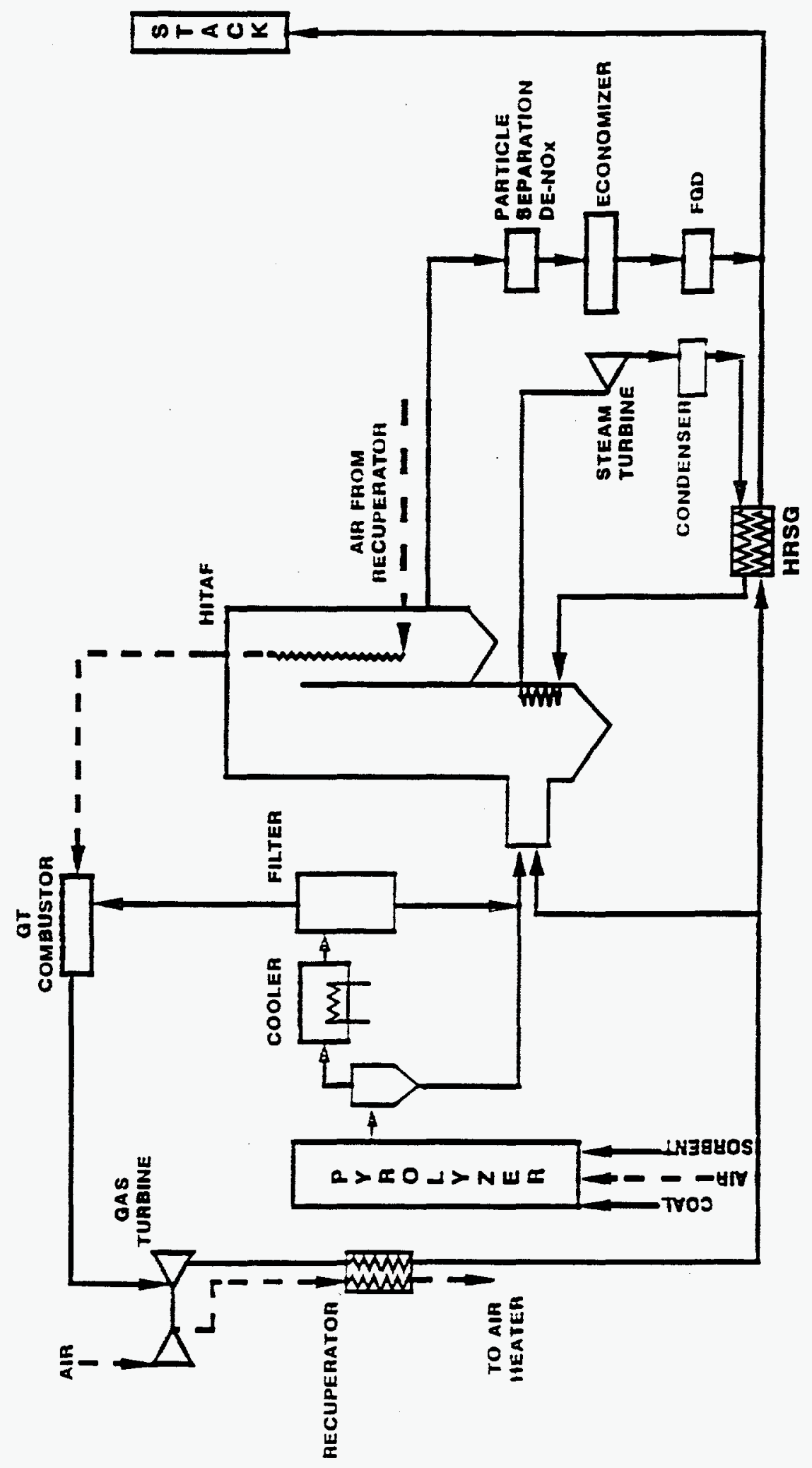

葛 
A schematic of an alternative HIPPS cycle is shown in Figure 2. This arrangement uses a ceramic air heater to heat the air to temperatures above what can be achieved with alloy tubes. This arrangement is referred to as the 35-percent natural gas HIPPS. A pyrolyzer is used as in the base-case HIPPS, but the fuel gas generated is fired upstream of the ceramic air heater instead of in the topping combustor. Gas turbine air is heated to $760^{\circ} \mathrm{C}\left(1400^{\circ} \mathrm{F}\right)$ in alloy tubes the same as in the All Coal HIPPS. This air then goes to the ceramic air heater where it is heated further before going to the topping combustor. The temperature of the air leaving the ceramic air heater will depend on technological developments in that component. An air exit temperature of $982^{\circ} \mathrm{C}\left(1800^{\circ} \mathrm{F}\right)$ will result in 35 percent of the heat input from natural gas.

\section{TECHNICAL PROGRESS}

\section{Task 1 - Project Planning and Management}

During this Quarter, Foster Wheeler Energy Corporation (FWEC) was substituted for TRW as the supplier of the char combustion system. FWEC has years of commercial experience in burning lowvolatile fuels, and their arch-fired combustion system has always been an option for HIPPS. The proposal was modified to substitute FWEC for TRW. The R\&D that was to be done by TRW will still be done, but it will be done by FWEC on their combustion system.

During this reporting period, Bechtel's activities continued to be focused on improving the performance and operability of the all-coal feed version of the commercial plant design. Specifically, the areas receiving attention included:

- Modifying operating parameters to either adjust for changes in equipment specifications or to improve overall plant performance. Areas modified during the current reporting period include:

- Examining the effect of adjusting the air temperature leaving the primary (alloy) air heater

- Replacing the TRW slagging combustors with FW burners

- Examining the effect of increasing the temperature to the gas turbine

- Removing the supplemental coal feed to the furnace. 


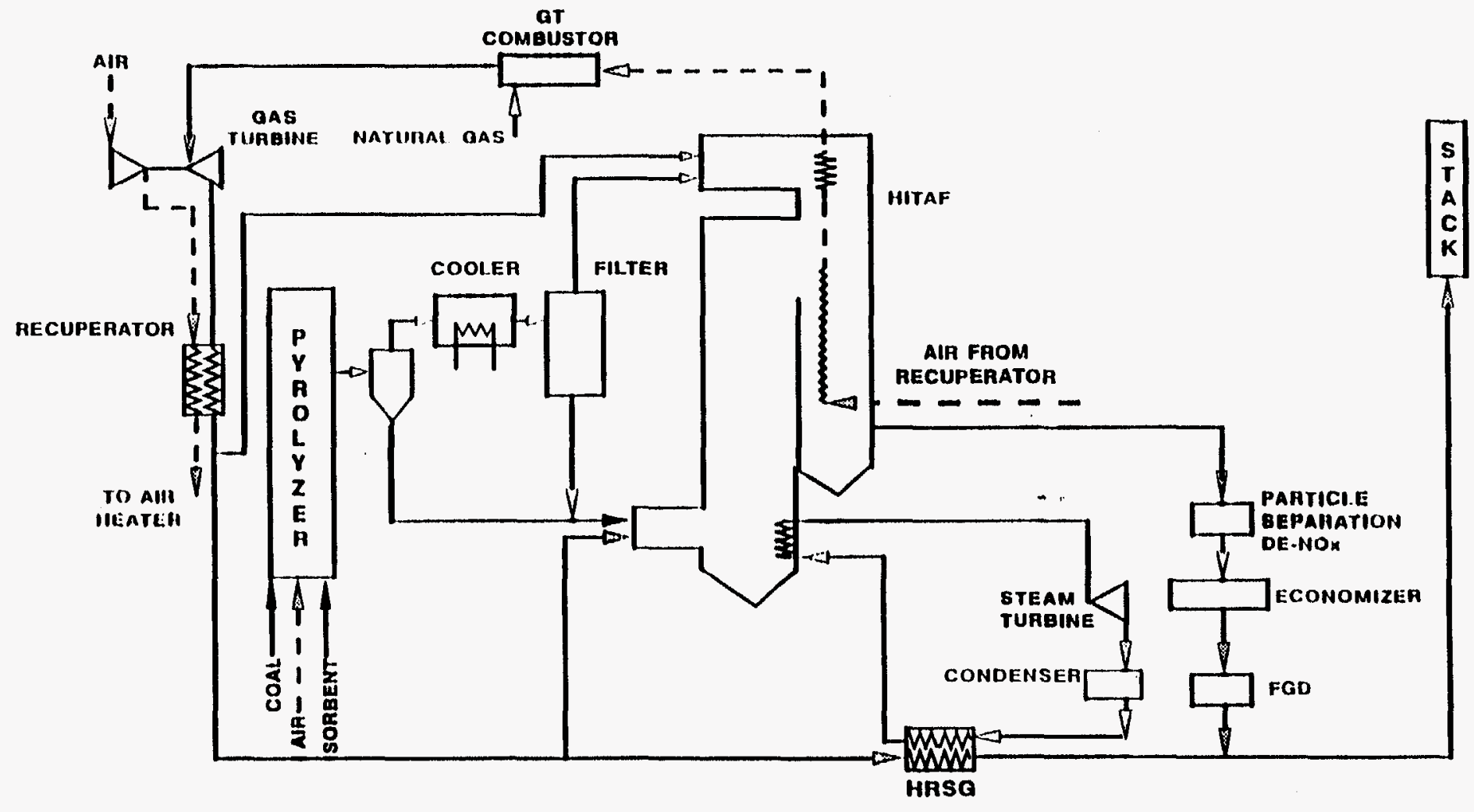

Figure 2 35-Percent Natural Gas HIPPS 
- Looking at possible modifications in the steam bottoming cycle to improve operability including:

- Adding low-pressure boilers

- Relocating some superheaters/reheaters

- Changing the pyrolysis fuel gas cooler from superheater to a high-pressure BFW heater

- Changing the BFW flow configuration.

The impact of increasing the temperature limits surrounding the ceramic exchanger in the partial natural gas-fired version of the commercial design was also investigated.

Additional information on each of these topics follows.

\section{Modifying the Commercial Design Operating Parameters}

Changing air heater temperatures. The initial phases of the work in this area were reported last quarter. It included the examination of the impact of adding water, by various means, to the pyrolyzer system. It was found that injection of high levels of steam into the pyrolyzer appeared to offer the best means to improve the overall system performance. It was found that increasing the level of steam increased the production of fuel gas at the expense of char production. This increased the amount of energy in the coal going to the gas turbine and, in return, reduced the amount going to the bottoming cycle, thereby improving the overall system performance.

During this reporting period, this analysis was taken one step further. Logically, as the amount of char is reduced, the point is reached where there is insufficient high-level heat to sustain an accepable level of efficiency for the steam system. For the $166 \mathrm{bar} / 580^{\circ} \mathrm{C} / 580^{\circ} \mathrm{C}(2400$ $\mathrm{psig} / 1075^{\circ} \mathrm{F} / 1075^{\circ} \mathrm{F}$ ) steam system currently employed, nearly 60 percent of the heat would be considered high-level heat required for evaporation, superheating, or reheating. The other $40+$ percent is used to heat boiler feed water (BFW). The effect of changing this ratio was confirmed during the last quarter when it was found that for very high pyrolysis steam loadings, the heat rate for the bottoming cycle increased dramatically when the temperatures of the exhaust gas leaving the economizers could not be maintained because of reduced BFW flows.

Although the vitiated air flow going to the clean-side evaporators and economizers is more than twice the gas passing through the furnace, the furnace is the key source of high-level heat since the vitiated air leaving the recuperator is only about $480^{\circ} \mathrm{C}\left(896^{\circ} \mathrm{F}\right)$. The effect of char on furnace operation has been studied, but there is another key user of high-level heat. It is the tube banks in the HITAF that heat the gas turbine air. Almost since project inception, the temperature of the air leaving this air heater has been maintained at $760^{\circ} \mathrm{C}\left(1400^{\circ} \mathrm{F}\right)$. This level was set based on material considerations. The question was posed: What would be the effect if this temperature were allowed to float?

As noted above, ideally the process should have about 50 percent more high-level heat available than low-level heat in order to match the steam cycle. If the temperature of the air leaving the air heater 
were allowed to float, then the amount of high-level heat available to the steam cycle could be tailored to provide the nominal $60 / 40$ split required, i.e., for every level of char production, there should be an air heater exit temperature that will leave the proper amount of high-level heat for the bottoming cycle.

A series of GateCycle and spreadsheet runs confirmed this hypothesis, and the results are presented in Figures 3 and 4. Also shown is the impact of increasing the gas turbine inlet temperature. This topic will be discussed in more detail below. As can be seen from Figure 3, an outlet temperature of $760^{\circ} \mathrm{C}\left(1400^{\circ} \mathrm{F}\right)$ is actually only optimum for a steam injection level of about $0.43 \mathrm{~kg} / \mathrm{kg}$ of coal feed. Fortunately, this is the level previously reported as the dry feed, high-steam case (DF-HS) which was the case chosen to be the proposed New Base Case for the commercial plant design.

The general trend shown in Figure 3 is understandable. As the steam injection level is increased, the char production is decreased. The reduction in char means less heat is available in the furnace. This must be offset by lowering the heat requirements of the air heater to maintain the proper ratio of high-/low-level heat for the bottoming cycle.

Figure 4 presents the estimated overall performance at the various pyrolysis steam levels. It can be seen that above about $0.55 \mathrm{~kg} / \mathrm{kg}$-coal the performance drops off rapidly and that there appears to be a maximum around $0.30-0.35 \mathrm{~kg} / \mathrm{kg}$-coal. The maximum is the result of offsetting factors.

As discussed above, at low steam rates, there is an increase in the amount of char and subsequently the amount of steam to the bottoming cycle. When the temperature of the air heater is allowed to float, this is offset by the increase in air heater temperature which means more energy from the char is being picked up by the air. This allows more energy to be used in the gas turbine before being picked up by the steam system.

At steam flows below about $0.30 \mathrm{~kg} / \mathrm{kg}$-coal, the fraction of energy going to steam begins to be dominant, and the overall performance suffers. The reverse is true at the high end of steam injection. The reduced production of char reduces the amount of steam, but to balance the high-/low-heat loads, the air heater temperature must be reduced. This means less energy from the char goes to the gas turbine and also that more fuel must be produced to make up for the lower temperature of the air reaching the GT combustor.

What this set of calculations indicates is that 1) there is an optimum point, from a performance standpoint, and 2) there is a reasonably broad range of operating conditions where the performance is nearly constant, as seen in Figure 4, between about 0.20 and $0.50 \mathrm{~kg}$ steam $/ \mathrm{kg}$-coal. This means that the decision on where to operate within this range depends on capital costs and the capabilities of new materials being considered for the air heater.

It should be noted that the data presented in Figures 3 and 4 are off the Bechtel spreadsheet simulation, and while they match the GateCycle runs reasonably well, the absolute values are slightly different. Nevertheless, the trends displayed are accurate and the level of change is also considered representative. 


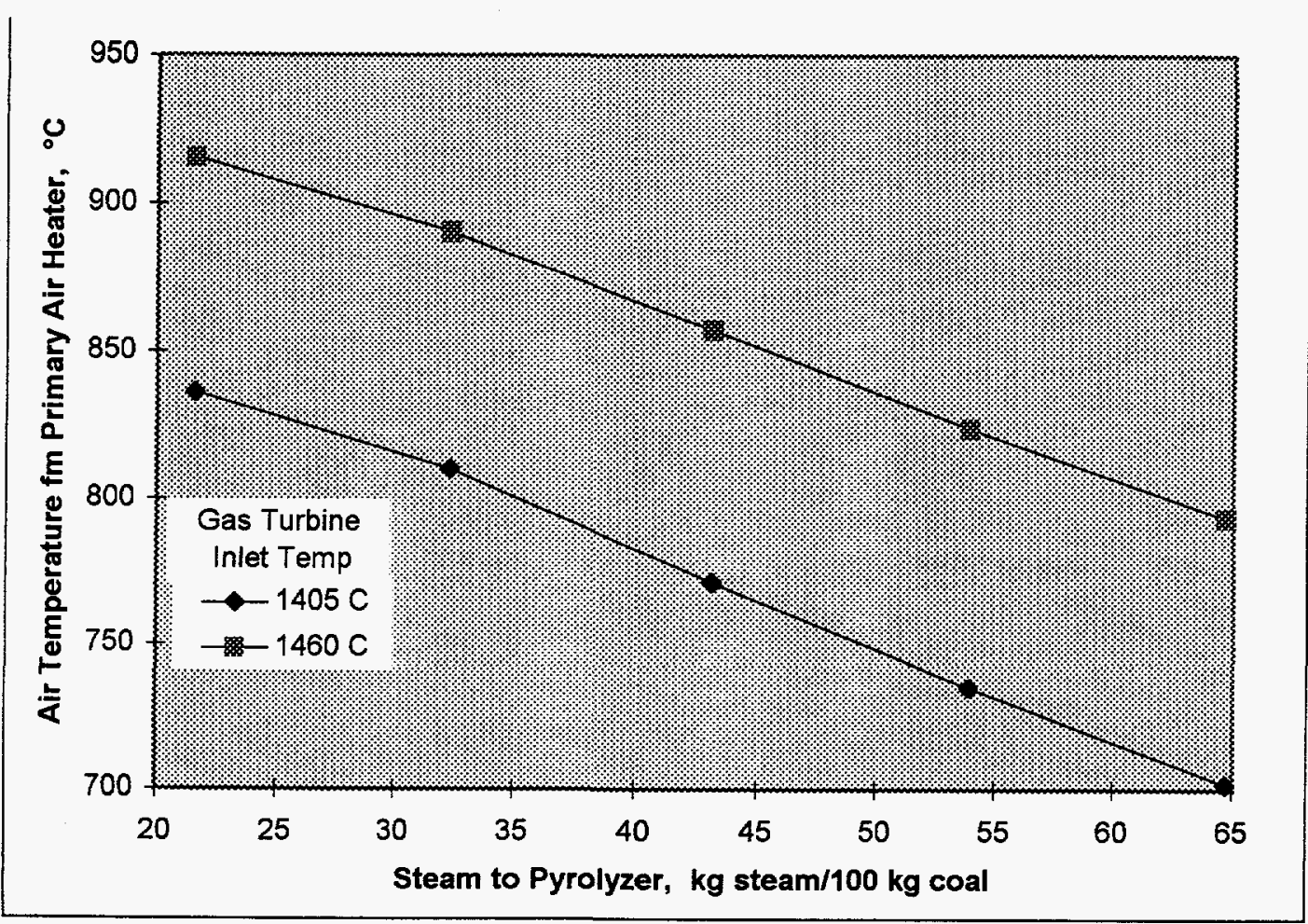

Figure 3

Relationship of Steam to Pyrolyzer and Air Heater Temperature

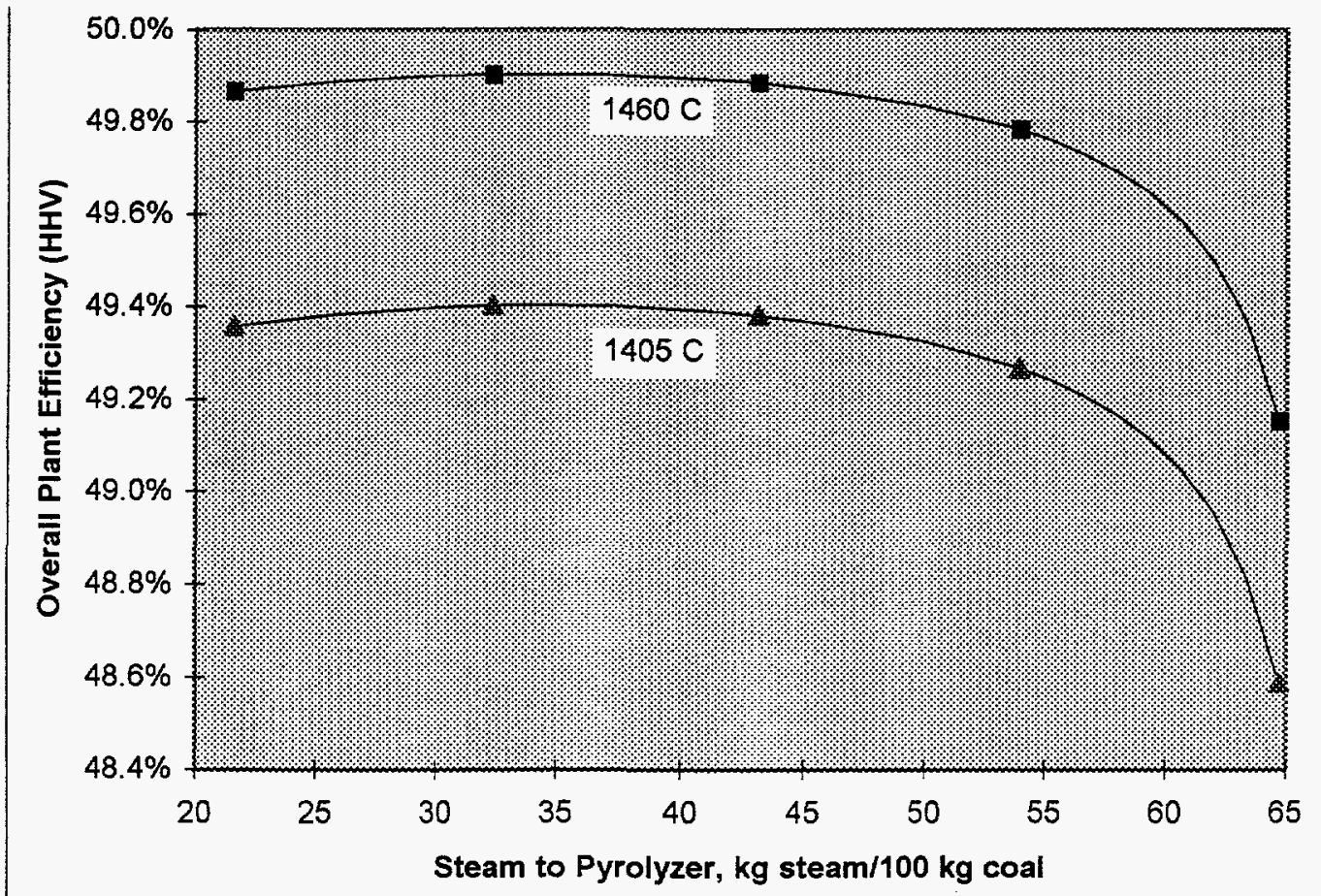

Figure 4

Relationship of GT Inlet Temperature and Steam Flow to Pyrolyzer on Plant Efficiency 
Replacing the TRW slagging combustors. Concurrent with the changes being made in the air heater temperature, the new runs also include the conversion from TRW slagging combustors to FW burners. This involved a couple of changes. First, the TRW combustors incorporated an evaporative cooler that provided a significant amount of the steam generation capacity within the bottoming cycle. This capacity was assumed to be transferred to the furnace as part of the water wall surface.

The second item is more significant, especially in its impact on the overall efficiency. TRW had specified a certain amount of coal to be fed to the preliminary combustor where the primary air was heated before contacting the char in the main combustor. The amount of coal specified provided about 20 percent of the energy to the slagging combustors. It should be noted that any energy supplied by the coal goes directly to the bottoming cycle since the air going to the gas turbine is already being heated by the char. The amount of coal needed for the FW burners will be determined in Phase 2, but it is estimated that it would be from zero to 10 percent. The current balance is at zero percent. This improved the overall efficiency about 1 percentage point. Removing the coal also reduced the amount of high-level heat which also impacted the calculations discussed above.

As part of Phase 2, FWEC will evaluate char as a fuel to determine whether some coal may be required to provide flame stability. Initial testing of the char as part of the Phase 1 program indicated that it was fairly reactive, and it is hoped that coal may only be needed during start-up and/or offload operating conditions.

Increasing the inlet temperature to the gas turbine. The combustion temperatures used by state-ofthe-art main frame and aeroderivative gas turbines continue to climb. Interest was expressed in what effect a high combustion temperature might have on the overall efficiency. The temperature currently used is $1405^{\circ} \mathrm{C}\left(2561^{\circ} \mathrm{F}\right)$ leaving the combustor. This was arbitrarily increased by $55^{\circ} \mathrm{C}$ $\left(131^{\circ} \mathrm{F}\right)$ to $1460^{\circ} \mathrm{C}\left(2600^{\circ} \mathrm{F}\right)$. The results are presented in Figures 3 and 4.

Based on the results to date, it appears that increasing the temperature provides about a 0.5 percentage point increase in overall efficiency. Typically, such an increase in simple cycle and combined cycle gas turbine systems would provide a greater improvement in overall efficiency. However, such changes in inlet temperatures are usually accompanied by corresponding increases in the compression ratio to maximize the gross power production and reduce the heat losses from the turbine exhaust. The current examination did not attempt to adjust the pressure from the compressor since it impacts on so many pieces of equipment. Bechtel will work with Westinghouse to determine what operating conditions should be used if there is continued interest in evaluating the new G-frame machines in a HIPPS configuration.

\section{New Base Balance}

It appeared, from the GateCycle runs carried out in parailel with the spreadsheet analysis presented in Figures 3 and 4, that a near-maximum performance was available using the DF-HS steam loading reported in the previous quarter. These were modified to allow for the replacement of the TRW combustors and for an air heater outlet temperature adjusted to $750^{\circ} \mathrm{C}\left(1385^{\circ} \mathrm{F}\right)$. This is very close to the $760^{\circ} \mathrm{C}\left(1400^{\circ} \mathrm{F}\right)$ used previously. 
Although some modifications may take place as a result of possible changes in the bottoming cycle (discussed below) and from future economic analyses, it was decided that the current balance was sufficiently close to allow Westinghouse to evaluate the conditions surrounding the gas turbine. Current runs still employ operating conditions suggested by General Electric during the Phase 1 program. Upon receipt of the Westinghouse data, the optimum point will be reconfirmed, and a brief economic analysis will be made to determine the optimum operating conditions for the material balance to be used during Phase 2. It will also serve to provide a basis for the revised capital cost estimate for the commercial plant. The process streams for the heat and material balance are shown in Figure 5. The performance and summary material balance are presented in Tables 1 and 2.

\section{Possible Bottoming Cycle Modifications}

The design of the commercial plant is reaching the point where it was felt that a review of some operability and constructability aspects was considered warranted. This work is still ongoing, but some of the items being considered include:

- High-temperature steam pipe is expensive. This is especially true for piping associated with the reheat system since the pressure is much lower and, therefore, the diameter of the pipe is greater. Thus some thought should be given to limiting the length of these lines by minimizing the transfer of reheat steam between various pieces of equipment. The current design employs three reheaters. These are being examined to see whether they can be relocated or combined.

- The fuel gas cooler, while not unique, is a special piece of equipment. British Coal includes an elaborate fuel gas cooler in their topping cycle design employing evaporators and superheaters. Nevertheless, this can be difficult to design and operate, and can be expensive. To simplify the design of this exchanger, its conversion from a second-stage superheater to a high-pressure BFW heater is being considered.

- To aid start-up and shutdown, the addition of two low-pressure boilers operating at about 45 psia and located between the high- and low-pressure economizers on both the clean and dirty flue gas streams is being evaluated. The low-pressure steam would be superheated to about $440^{\circ} \mathrm{C}$ $\left(824^{\circ} \mathrm{F}\right)$ and sent to the LP steam turbine. The inclusion of a LP boiler could preclude the need for an auxiliary boiler during start-up.

- The flue gas leaving the clean-side economizers is at a much lower temperature than that for the dirty side, nominally $102^{\circ} \mathrm{C}\left(216^{\circ} \mathrm{F}\right)$ versus $129^{\circ} \mathrm{C}\left(264^{\circ} \mathrm{F}\right)$. A modification in the condensate routing leaving the steam turbine condenser takes advantage of that fact by routing all the condensate through the clean side first before splitting. 


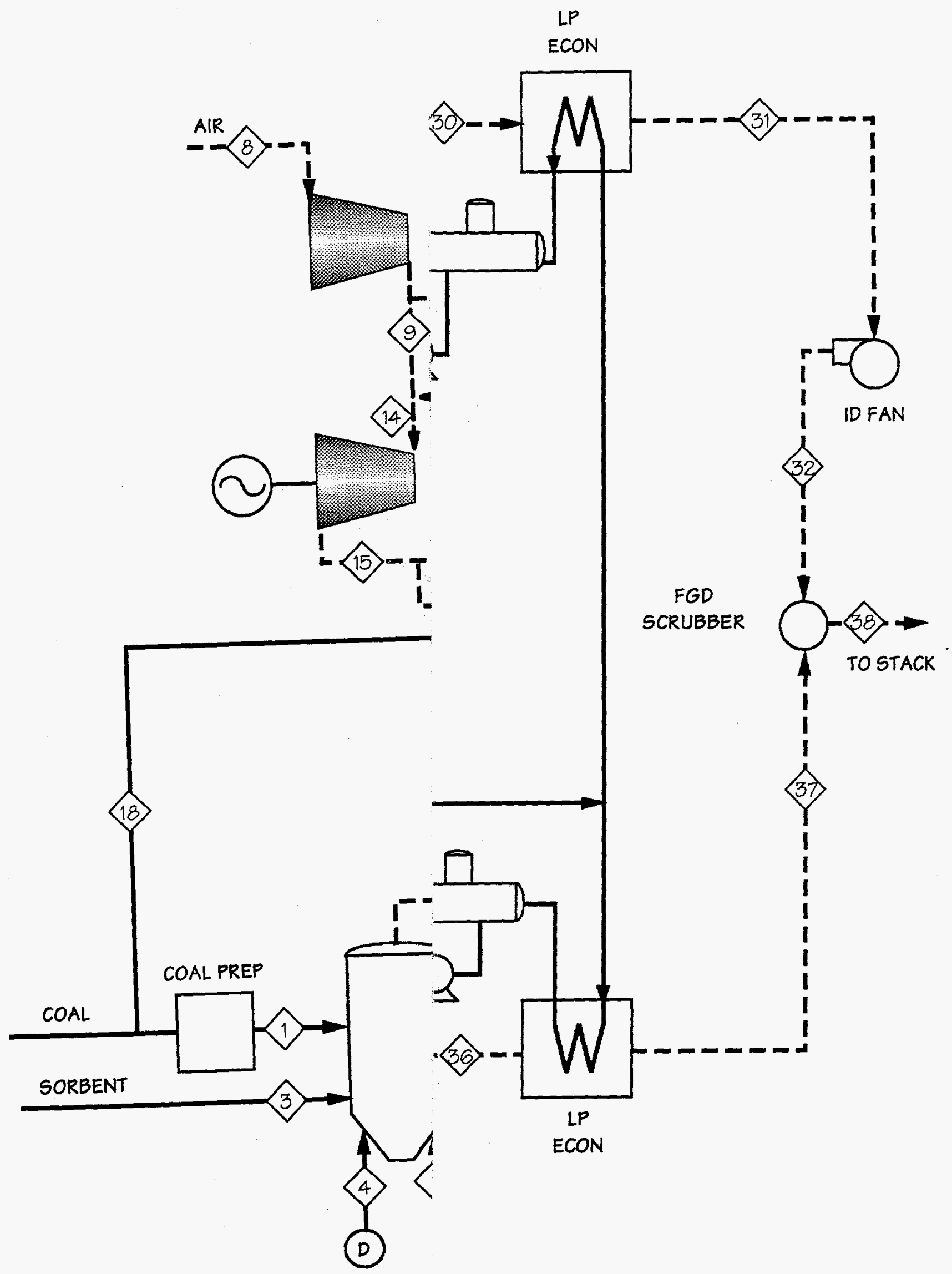


Table 1

Performance Summary

\begin{tabular}{|c|c|c|}
\hline Coal Flow & $\mathrm{kg} / \mathrm{h}$ & 69,126 \\
\hline Limestone & $\mathrm{kg} / \mathrm{h}$ & 6,514 \\
\hline Steam & $\mathrm{kg} / \mathrm{h}$ & 28,757 \\
\hline Fuel Gas & $\mathrm{kg} / \mathrm{h}$ & 235,454 \\
\hline Char & $\mathrm{kg} / \mathrm{h}$ & 27,332 \\
\hline Air Heater Temperature & $\mathrm{C}$ & 752 \\
\hline Gas Turbine Power & MWe & 154.56 \\
\hline Steam Turbine Power & $\mathrm{MWe}$ & 135.01 \\
\hline Gross Power & MWe & 289.57 \\
\hline Auxiliary Power & MWe & 13.01 \\
\hline Net Power & MWe & 276.56 \\
\hline Heat Rate & $\mathrm{kJ} / \mathrm{kWh}$ & 7,236 \\
\hline Overall Efficiency (\%) & & 49.73 \\
\hline
\end{tabular}


Table 2

Major Process Flow Streams - All Coal Commercial Case High Steam

\begin{tabular}{|c|c|c|c|c|c|c|c|c|c|c|c|c|c|c|c|c|}
\hline \multirow[t]{2}{*}{ Stream No. } & \multicolumn{2}{|c|}{1} & \multicolumn{2}{|c|}{2} & \multirow{2}{*}{\multicolumn{2}{|c|}{$\frac{3}{\text { Sorbent to Pyrolyzer }}$}} & \multirow{2}{*}{\multicolumn{2}{|c|}{$\frac{4}{\text { Steam to Pyrolyzer }}$}} & \multirow{2}{*}{\multicolumn{2}{|c|}{$\frac{5}{\text { Char fm Pyrolyzer }}$}} & \multirow{2}{*}{\multicolumn{2}{|c|}{$\frac{6}{\text { Fuel Gas fm Pyrolyzer }}$}} & \multirow{2}{*}{\multicolumn{2}{|c|}{$\frac{7}{\text { Fuel Gas ím Cooler }}$}} & \multirow{2}{*}{\multicolumn{2}{|c|}{$\frac{8}{\text { Alr to Compressor }}$}} \\
\hline & \multicolumn{2}{|c|}{ Coal to Pyrolyzer } & \multicolumn{2}{|c|}{ Air to Pyrolyzer } & & & & & & & & & & & & \\
\hline stream & kwt & $\mathrm{lb} / \mathrm{hr}$ & $\% w$ & $\mathrm{lb} / \mathrm{hr}$ & $\% \mathrm{wt}$ & lb/hr & kwt & lb/hr & $\% \mathrm{wt}$ & $\mathrm{l} \mathrm{b} / \mathrm{hr}$ & $\% \mathrm{mt}$ & $\mathrm{lb} / \mathrm{hr}$ & $\%$ wt & $\mathrm{lb} / \mathrm{hr}$ & $\% w t$ & $\mathrm{lb} / \mathrm{hr}$ \\
\hline Carbon & $71.92 \%$ & 105,663 & & & & & & & $56.45 \%$ & 34,013 & & & & & & \\
\hline Hydrogen & $4.69 \%$ & 6,890 & & & & & & & $0.36 \%$ & 214 & & & & & & \\
\hline Oxygen & $6.33 \%$ & 9,297 & & & & & & & & & & & & & & \\
\hline Nitrogen & $1.26 \%$ & 1,848 & & & & & & & $0.99 \%$ & 595 & & & & & & \\
\hline Sulfur & $2.99 \%$ & 4,398 & & & & & & & $0.93 \%$ & 563 & & & & & & \\
\hline Sollds & $10.32 \%$ & 15,156 & & & $0.95 \%$ & 136 & & & $25.39 \%$ & 15,299 & & & & & & \\
\hline Moisture & $2.50 \%$ & 3,673 & & & $2.00 \%$ & 287 & & & & & & & & & & \\
\hline $\mathrm{CaCO} 3$ & & & & & $85.50 \%$ & 13,716 & & & & & & & & & & \\
\hline $\mathrm{MgCO} 3$ & & & & & $1.55 \%$ & 223 & & & & & & & & & & \\
\hline $\mathrm{CaO}$ & & & & & & & & & $2.43 \%$ & 1,466 & & & & & & \\
\hline MgO & & & & & & & & & $0.18 \%$ & 106 & & & & & & \\
\hline Cas & & & & & & & & & $13.28 \%$ & 8,000 & & & & & & \\
\hline $\mathrm{CaSO}_{4}$ & & & & & & & & & & & & & & & & \\
\hline $\begin{array}{r}\mathrm{CH} 4 \\
\mathrm{C} 2 \mathrm{H} 4\end{array}$ & & & & & & & & & & & $1.21 \%$ & 6,265 & $1.21 \%$ & 6,222 & & \\
\hline $\begin{array}{l}\mathrm{C} 2 \mathrm{H} 4 \\
\mathrm{C} 2 \mathrm{H} 6\end{array}$ & & & & & & & & & & & & & & & & \\
\hline $\mathrm{C} 3 \mathrm{H}$ & & & & & & & & & & & & & & & & \\
\hline $\mathrm{co}$ & & & & & & & & & & & $21.04 \%$ & 109,216 & $21.04 \%$ & 108,454 & & \\
\hline Gases & & & & & & & & & & & $1.51 \%$ & 7,843 & $1.51 \%$ & 7,789 & & \\
\hline $\mathrm{co} 2$ & & & & & & & & & & & $15.39 \%$ & 79,887 & $15.39 \%$ & 79,330 & & \\
\hline $\mathrm{H} 2 \mathrm{O}$ & & & $0.82 \%$ & 2,895 & & & $100.00 \%$ & 63,398 & & & $8.48 \%$ & 44,034 & $8.48 \%$ & 43,727 & $0.82 \%$ & 26,970 \\
\hline 02 & & & $23.07 \%$ & 81,901 & & & & & & & & & & & $23.07 \%$ & 763,060 \\
\hline $\mathrm{N} 2$ & & & $76.11 \%$ & 270,186 & & & & & & & $52.16 \%$ & 270,756 & $52.16 \%$ & 268,866 & $78.11 \%$ & $2,517,270$ \\
\hline $\mathrm{H} 2 \mathrm{~S}$ & & & & & & & & & & & $0.06 \%$ & 297 & $0.06 \%$ & 295 & & \\
\hline $\begin{array}{l}\mathrm{cos} \\
\mathrm{sO} 2\end{array}$ & & & & & & & & & & & & & & & & \\
\hline $\mathrm{C} 6 \mathrm{H} 6+$ & & & & & & & & & & & & & & & & \\
\hline Argon & & & & & & & & & & & & & & & & \\
\hline $\mathrm{NH} 3$ & & & & & & & & & & & $0.15 \%$ & 786 & $0.15 \%$ & 781 & & \\
\hline $\mathrm{NO} 2$ & & & & & & & & & & & & & & & & \\
\hline Total Flow, lb/h/ & $100.00 \%$ & 146,925 & $100.00 \%$ & 354,982 & $100.00 \%$ & 14,362 & $100.00 \%$ & 63,398 & $100.00 \%$ & 60,257 & $100.00 \%$ & 519,087 & $100.00 \%$ & 515,462 & $100.00 \%$ & $3,307,300$ \\
\hline M/H & & & & 12,365 & & & & & & & & 22,160 & & 22,006 & & 115,203 \\
\hline $\mathbf{M w}$ & & & & 28.71 & & & & & & & & 23.42 & & 23.42 & & 28.71 \\
\hline Pressure, psia & & 258.20 & & 263.90 & & 258.20 & & 232.52 & & 238.22 & & 238.22 & & 228.22 & & 14.60 \\
\hline Temperature, ${ }^{\circ} \mathrm{F}$ & & 70.00 & & 405.10 & & 70.00 & & 415.00 & & $1,700.00$ & & $1,700.00$ & & $1,100.00$ & & 70.00 \\
\hline Temperature, ${ }^{\circ} \mathrm{C}$ & & 21.11 & & 207.28 & & 21.11 & & 212.78 & & 926.67 & & 926.67 & & 593.33 & & 21.11 \\
\hline Sens. Heat, MM Btu/hr & & 0.39 & & 33.17 & & 0.04 & & 10.24 & & 25.71 & & 293.03 & & 177.45 & & 8.86 \\
\hline Lat. Heat, MM Btu/hr & & & & 3.04 & & & & 66.57 & & & & 46.24 & & 45.91 & & 28.32 \\
\hline L.HV, Btu/ib & & 12.445 .05 & & & & & & & 8.931 .58 & 8,96295 & 1.964 .71 & $1,967.29$ & & $1,967.29$ & & \\
\hline HHV, Btu/lb & & $12,915.83$ & & & & & & & $8,966.16$ & $8,996.60$ & $2,215.40$ & $2,200.44$ & & $2,200.44$ & & \\
\hline LHV, MM Btu/hr & & $1,828.49$ & & & & & & & & 540.08 & & $1,021.20$ & & $1,014.07$ & & \\
\hline HHV, MM Btu/hr & & $1,897.66$ & & & & & & & & 542.11 & & $1,142.22$ & & $1,134,24$ & & \\
\hline Total Energy, LHV & & $1,828.88$ & & 33.17 & & 0.04 & & 10.24 & & 565.79 & & $1,314.22$ & & $1,191.51$ & & 8.86 \\
\hline MM Btu/h, & & $1,898.05$ & & 36.21 & & 0.04 & & 76.81 & & 567.81 & & $1,435.25$ & & $1,311,69$ & & 37.17 \\
\hline
\end{tabular}


Table 2 (cont)

Major Process Flow Streams - All Coal Commercial Case

High Steam

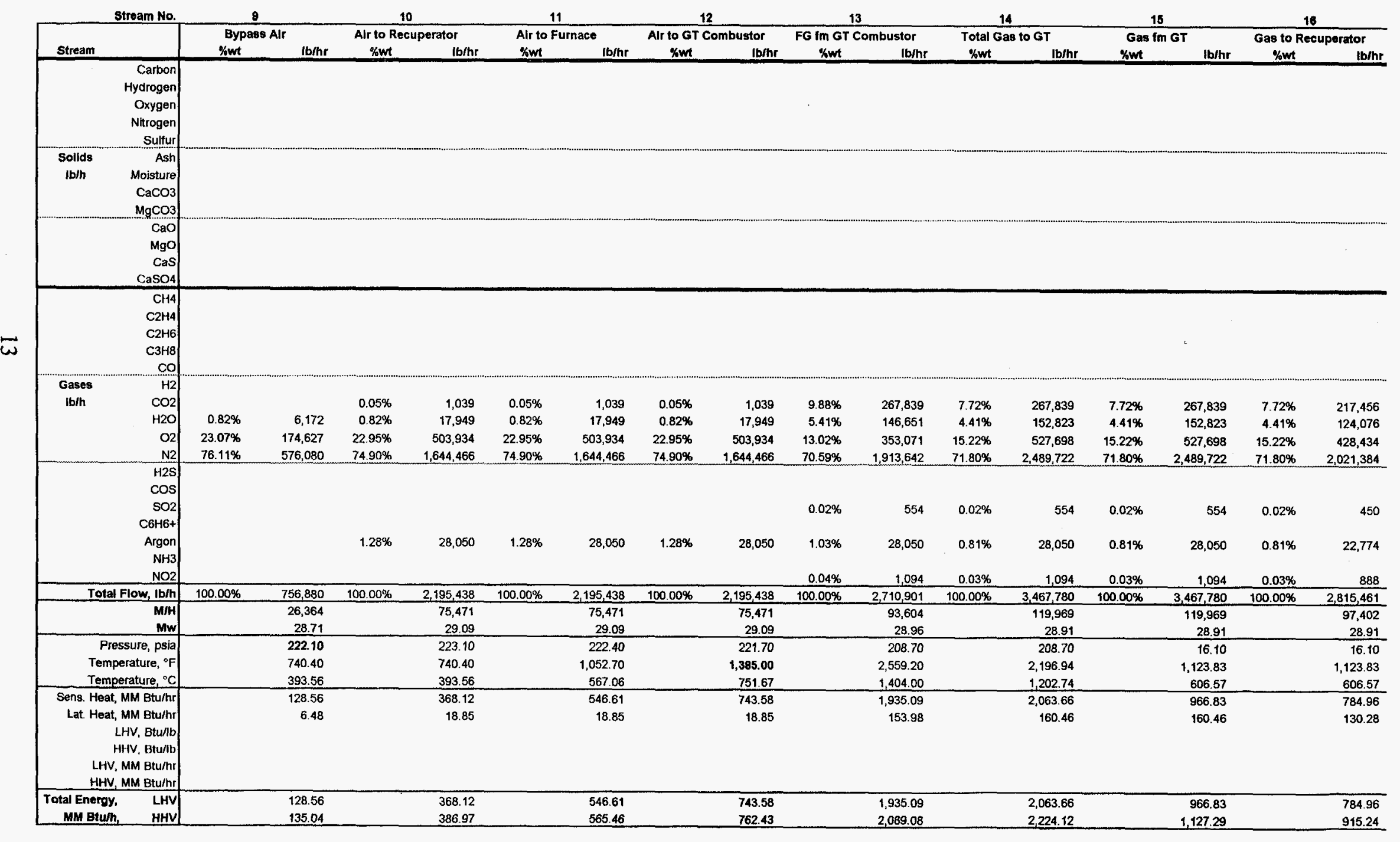


Table 2 (cont)

Major Process Flow Streams - All Coal Commercial Case

High Steam

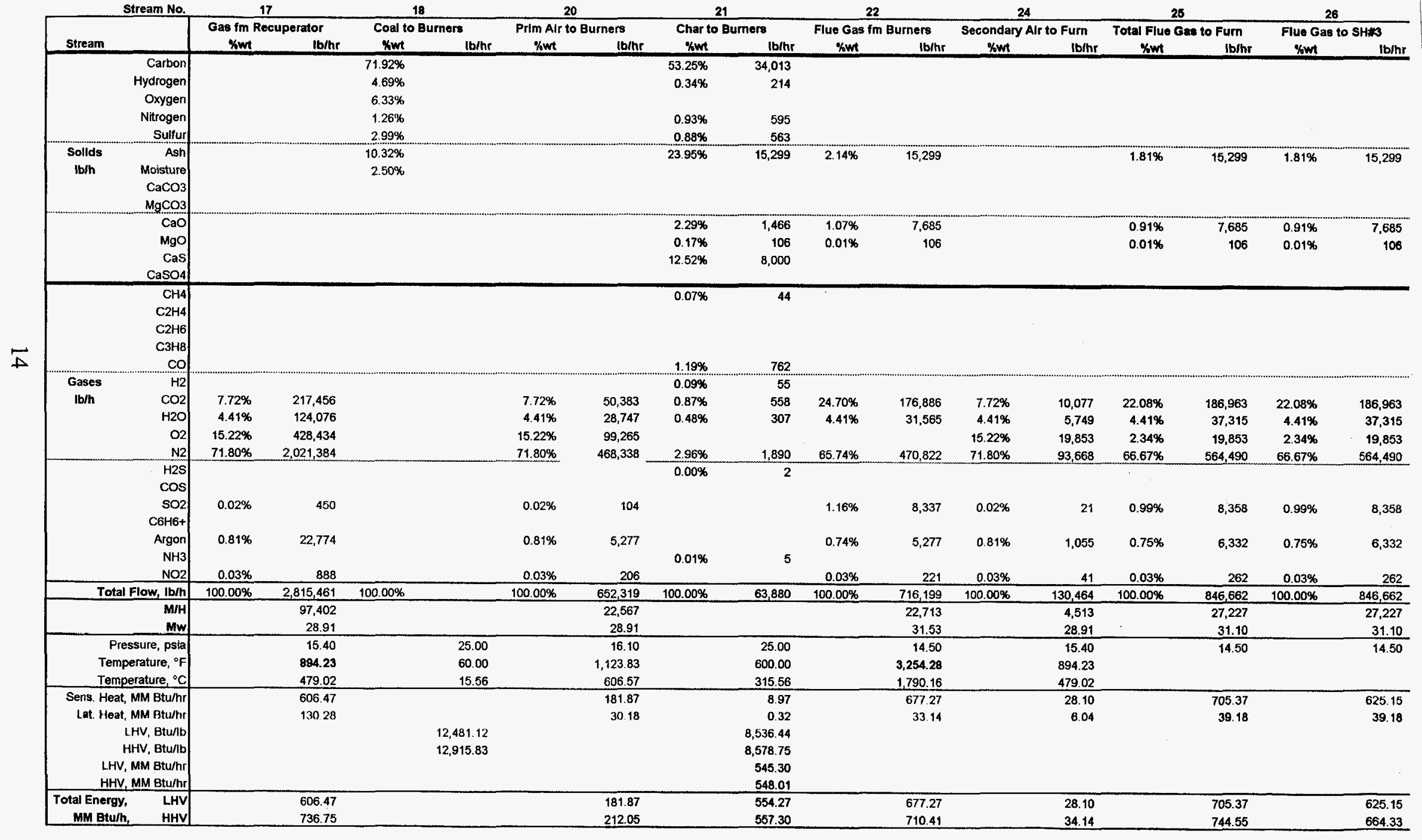


Table 2 (cont)

Major Process Flow Streams - All Coal Commercial Case

High Steam

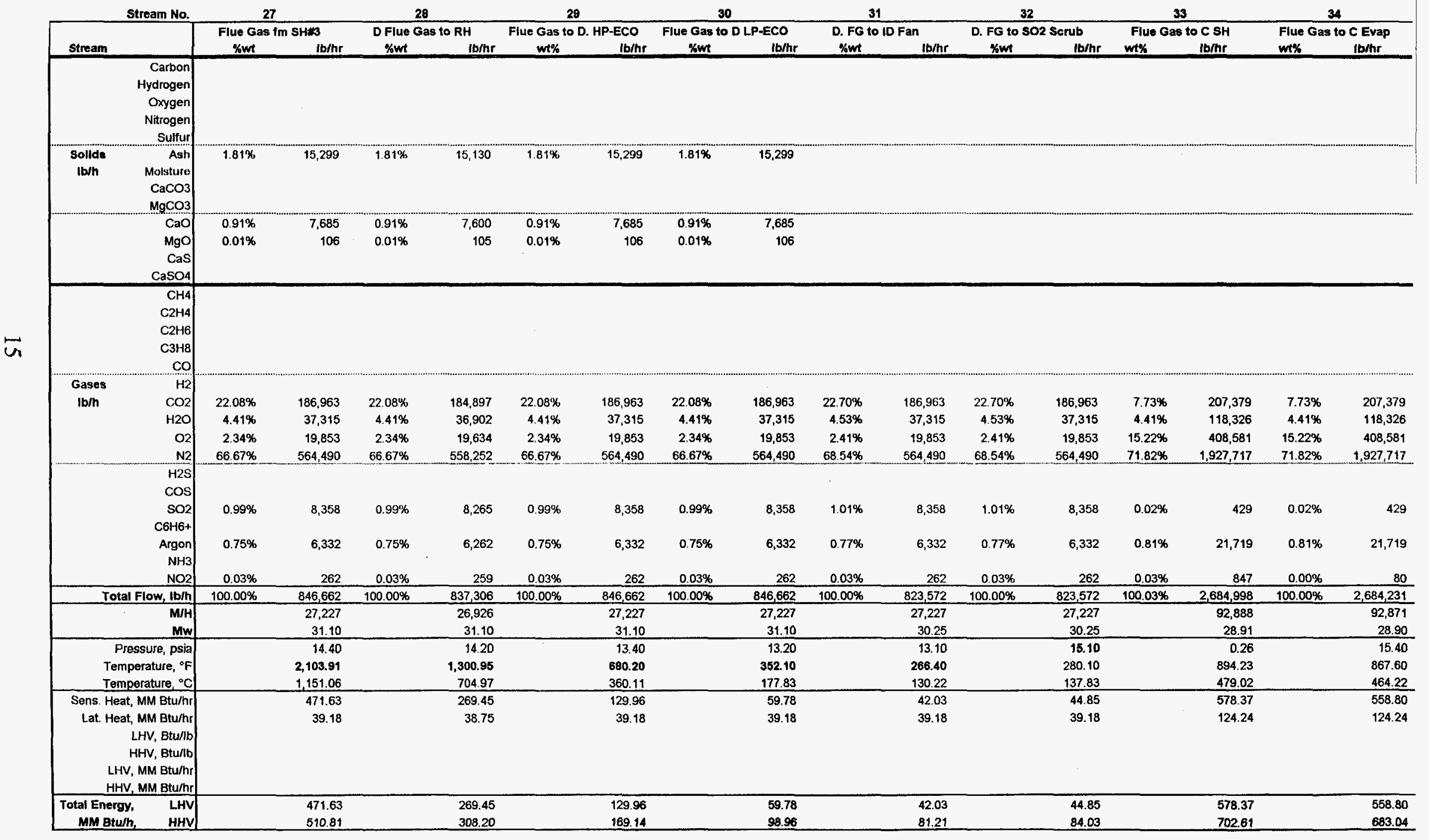


Table 2 (cont)

Major Process Flow Streams - All Coal Commercial Case

High Steam

\begin{tabular}{|c|c|c|c|c|c|c|c|c|}
\hline Stream No. & & & & & & & & \\
\hline & FG to $C$. & Econ & FG to C & Econ & C. FG to & 2 Scrub & FG 1 & tack \\
\hline Stream & $w t \%$ & $\mathrm{lb} / \mathrm{hr}$ & $w+\%$ & $\mathrm{lb} / \mathrm{hr}$ & $w+x$ & lb/hr & wt\% & $\mathrm{d} / \mathrm{hr}$ \\
\hline Carbon & & & & & & & & \\
\hline $\begin{array}{r}\text { Hydrogen } \\
\text { Oxygen }\end{array}$ & & & & & & & & \\
\hline Nitrogen & & & & & & & & \\
\hline Sulfur & & & & & & & & \\
\hline Solids & & & & & & & & \\
\hline Moisture & & & & & & & & \\
\hline $\begin{array}{r}\mathrm{CaCO} 3 \\
\mathrm{MgCO} 3\end{array}$ & & & & & & & & \\
\hline $\mathrm{CaO}$ & & & & & & & & \\
\hline $\mathrm{MgO}$ & & & & & & & & \\
\hline $\begin{array}{r}\mathrm{CaS} \\
\mathrm{CaSO}\end{array}$ & & & & & & & & \\
\hline $\mathrm{CH} 4$ & & & & & & & & \\
\hline $\mathrm{C} 2 \mathrm{H} 4$ & & & & & & & & \\
\hline $\mathrm{C} 2 \mathrm{H} 6$ & & & & & & & & \\
\hline $\mathrm{C} 3 \mathrm{H} 8$ & & & & & & & & \\
\hline co & & & & & & & & \\
\hline $\begin{array}{l}\text { Gases } \\
\text { Ib/h }\end{array}$ & & & & & & & & \\
\hline $\begin{array}{cc}\mathrm{CO} 2 \\
\mathrm{H} 2 \mathrm{O}\end{array}$ & $7.73 \%$ & 207,379 & $7.73 \%$ & 207,379 & $7.73 \%$ & 207,379 & $11.93 \%$ & 394,342 \\
\hline $\mathrm{H} 2 \mathrm{O}$ & $4.41 \%$ & 118,326 & $4.41 \%$ & 118,326 & $4.41 \%$ & 118,326 & $5.63 \%$ & 199,687 \\
\hline $\mathrm{O} 2$ & $15.22 \%$ & 408,581 & $15.22 \%$ & 408,581 & $15.22 \%$ & 408,581 & $11.38 \%$ & 428,434 \\
\hline $\mathrm{N} 2$ & $71.82 \%$ & $1,927,717$ & $71.82 \%$ & $1,927,717$ & $71.82 \%$ & $1,927,717$ & $70.25 \%$ & $2,492,207$ \\
\hline $\mathrm{H} 2 \mathrm{~S}$ & & & & & & & & \\
\hline $\mathrm{sO} 2$ & $0.02 \%$ & 429 & $0.02 \%$ & 429 & $0.02 \%$ & 429 & $0.02 \%$ & 513 \\
\hline $\mathrm{C} 6 \mathrm{H} 6+$ & & & & & & & & \\
\hline $\begin{array}{r}\text { Argon } \\
\mathrm{NH}_{3}\end{array}$ & $0.81 \%$ & 21,719 & $0.81 \%$ & 21,719 & $0.81 \%$ & 21,719 & $0.78 \%$ & 28,050 \\
\hline $\mathrm{NO} 2$ & $0.00 \%$ & 80 & $0.00 \%$ & 80 & $0.00 \%$ & 80 & $0.00 \%$ & 106 \\
\hline Total Flow, Ib/h| & $100.00 \%$ & $2,684,231$ & $100.00 \%$ & $2,684,231$ & $100.00 \%$ & $2,684,231$ & $100.00 \%$ & $3,548,008$ \\
\hline $\mathrm{M} / \mathrm{H}$ & & 92,871 & & 92,871 & & 92,871 & & 122,319 \\
\hline Mw & & 28.90 & & 28.90 & & 28.90 & & 29.01 \\
\hline Pressure, psia & & 15.30 & & 15.10 & & 15.00 & & 14.70 \\
\hline Temperature, ${ }^{\circ} \mathrm{F}$ & & 692.60 & & 329.40 & & 217.60 & & 118.40 \\
\hline Temperature, "c & & 36700 & & 165.22 & & 103.11 & & 48.00 \\
\hline Sens. Heat, MM Btu/hr & & 432.93 & & 180.98 & & 105.64 & & 52.48 \\
\hline Lat. Heat, MM Btu/ms & & 124.24 & & 124.24 & & 124.24 & & 209.67 \\
\hline$L \mathrm{HV}, \mathrm{Btu} / \mathrm{b}$ & & & & & & & & \\
\hline HHV, Btu/lb & & & & & & & & \\
\hline LHV, MM Btu/hr & & & & & & & & \\
\hline LHV & & 432.93 & & 180.98 & & 105.6 & & 52.48 \\
\hline MM Btulh, & & 557.17 & & 305.23 & & 229.88 & & 262.15 \\
\hline
\end{tabular}

\begin{tabular}{|c|c|}
\hline \multicolumn{2}{|l|}{ Heat to Stm } \\
\hline SHH1 & $\mathrm{SH}$ \\
\hline 41.01 & 123.55 \\
\hline$\frac{E G \text { Comb }}{107.91}$ & \\
\hline SH世3 & Dirty He Econ \\
\hline 153.52 & 70.19 \\
\hline Dirty HRSG & Dirtu LP Econ \\
\hline 87.93 & 17.74 \\
\hline Clean HRSG & clean Exap \\
\hline 453.15 & 125.87 \\
\hline Precomb. & $\frac{\text { clean He Econ }}{251.94}$ \\
\hline$\frac{\text { char Comb. }}{58.87}$ & $\frac{\text { Clean LP Ecen }}{75.34}$ \\
\hline Reheater & Eurn Evap \\
\hline 68.99 & 42.99 \\
\hline Iotal & Iotal coal \\
\hline $1,137.93$ & $\begin{array}{r}146,925 \\
1,898.05\end{array}$ \\
\hline Steam Turbine & Heat Rate \\
\hline $135.14 \mathrm{MWe}$ & 8,420 \\
\hline & 8,571 \\
\hline$\frac{\text { GI }}{154.56}$ & $\frac{\text { Recuperator }}{178.49}$ \\
\hline Iotal Gross & Erim Air Hitr \\
\hline 289.70 & 196.97 \\
\hline $\begin{array}{l}\text { Net Paweer } \\
270.70\end{array}$ & $\begin{array}{l}\text { IDEan } \\
0.83 \text { MWo }\end{array}$ \\
\hline $\begin{array}{l}\text { Heat Rate } \\
6,859.61\end{array}$ & $\frac{\text { Booster Comp }}{1.34 \mathrm{MWe}}$ \\
\hline $49.76 \%$ & $\underset{10.83 \mathrm{MWe}}{\text { Misc. }}$ \\
\hline
\end{tabular}


- Implementation of some of these alternatives could adversely impact the overall performance of the system. A cost and performance benefit analysis will be carried out before final implementation is made.

A temperature increase for the ceramic air heater version of HIPPS was discussed among FWDC, AlliedSignal, and Westinghouse. It was indicated by Westinghouse that through the use of new materials they may be able to use a higher air temperature going to the combustor, perhaps as high as $1205^{\circ} \mathrm{C}\left(2200^{\circ} \mathrm{F}\right)$. The commercial design using the external ceramic exchanger was based on temperatures of $760^{\circ} \mathrm{C}\left(1400^{\circ} \mathrm{F}\right)$ leaving the alloy air heater and $982^{\circ} \mathrm{C}\left(1800^{\circ} \mathrm{F}\right)$ leaving the ceramic air heater (HTHE) going to the gas turbine combustor. Bechtel was asked to determine what impact raising the $\mathrm{HTHE}$ outlet temperature to $1205^{\circ} \mathrm{C}\left(2200^{\circ} \mathrm{F}\right)$ would have on overall plant performance.

It was obvious that the higher temperatures would reduce the natural gas requirements, but other changes were less predictable. Several spreadsheet cases were developed to uncover any trends. These were supported by two GateCycle runs for confirmation. The results from the spreadsheet runs are presented in Table 3.

On the surface it would appear that increasing the outlet temperature should improve the overall performance since it would put more energy from the fuel gas into the air, and hence, into the gas turbine. Generally, the greater the amount of energy from the coal that can be put into the gas turbine, the better. However, the larger demand of energy by the HTHE requires additional fuel gas from the pyrolyzer. Unfortunately, as the fuel gas increases, so does the char production. Since the amount of energy in the char used to heat the air in the primary heater is fixed, the energy from any additional char to the furnace goes directly to the bottoming cycle. The result is that what is gained in the HTHE is more than lost in the extra char to the furnace.

Based on the results obtained last quarter with steam feed to the pyrolyzer, a natural extension would be to increase the steam to the pyrolyzer for the natural gas configuration as well. The results from this analysis were also unexpected. Comparing Cases 1 through 3 and 4 through 5 , it can be seen that increasing the steam to the pyrolyzer had a negative impact on overall plant performance. This contradicts the results obtained for the configuration used in the "all coal" design.

The reason for the drop appears to be the cumulative effect of several factors. First, unlike the "all coal" case where increasing the water content resulted in an increase in power from the gas turbine because of the increase in mass flow, in the ceramic air heater system the gas turbine power remains constant. Since the primary air heater temperature was not allowed to change as the amount of char to the furnace was reduced, the size of the bottoming cycle was also reduced. Generally, this would be good. However, without changing the air heater temperature to help balance the high- and lowlevel heat sources, the bottoming cycle gradually becomes less efficient. While this analysis was very brief, it appears from the results in Table 3 that the benefits of increasing the ratio of gas turbine to steam turbine power is more than offset by the loss in efficiency of the bottoming cycle. This would have to be confirmed in a more detailed analysis. Whether there is a slight drop in efficiency, as shown in Table 3, or a slight rise (if the algorithm used for the steam system was too severe), the 
Table 3

\section{Summary of Indirect Heating Results}

\begin{tabular}{|c|c|c|c|c|c|c|c|c|c|}
\hline HTHE Inlet Temp & C & $\frac{\text { Ref Case }}{760}$ & $\frac{\text { Case 1 }}{760}$ & $\frac{\text { Case 2 }}{760}$ & $\frac{\text { Case } 3}{760}$ & $\frac{\text { Case 4 }}{760}$ & $\frac{\text { Case 5: }}{760:}$ & $\frac{\text { Case } 6}{760}$ & $\frac{\text { Case } 7}{871}$ \\
\hline HTHE Outlet Temp & c & 927 & 927 & 927 & 927 & 1,204 & 1,204 & 1,204 & 1,204 \\
\hline Coal to Pyrolyozer & $\mathrm{kg} / \mathrm{h}$ & 49,550 & 54,818 & 45,008 & 43,481 & 117,258 & 95,348 & 91,646 & 73,874 \\
\hline Coal to Char Burner & $\mathrm{kg} / \mathrm{h}$ & 4,955 & 5,482 & 4,501 & 4,348 & 11,726 & 9,535 & 9,165 & 7,387 \\
\hline Natural Gas & $\mathrm{kg} / \mathrm{h}$ & 15,009 & 15,009 & 15,009 & 15,009 & 6,372 & 6,372 & 6,372 & 6,372 \\
\hline Total Energy In & $\mathrm{kJ} / \mathrm{h} \times 10^{6}$ & 2,498 & 2,650 & 2,380 & 2,354 & 4,234 & 3,625 & 3,554 & 2,889 \\
\hline $\begin{array}{l}\text { Steam to Pyrolyzer } \\
\text { Char to Combustor }\end{array}$ & $\begin{array}{l}\mathrm{kg} / \mathrm{kg} \text { coal } \\
\mathrm{kg} / \mathrm{h}\end{array}$ & $\begin{array}{c}16.18 \\
23,693\end{array}$ & $\begin{array}{r}0.00 \\
33,543\end{array}$ & $\begin{array}{c}43.15 \\
19,382\end{array}$ & $\begin{array}{r}64.73 \\
15,997\end{array}$ & $\begin{array}{r}0.00 \\
71,748\end{array}$ & $\begin{array}{r}43.15 \\
41,059\end{array}$ & $\begin{array}{r}64.73 \\
33,718\end{array}$ & $\begin{array}{r}43.15 \\
31,812\end{array}$ \\
\hline Gas Turbine & MWe & 130.6 & 130.6 & 130.6 & 130.6 & 123.4 & 123.4 & 123.4 & 123.4 \\
\hline Steam Turbine & MWe & 213.7 & 241.4 & 195.0 & 177.7 & 386.0 & 299.1 & 269.9 & 249.6 \\
\hline Gross Power & MWe & 344.3 & 372.0 & 325.6 & 308.3 & 509.4 & 422.5 & 393.3 & 373.1 \\
\hline Total Auxiliary Power & MWe & 9.1 & 9.6 & 8.5 & 8.2 & 19.0 & 13.4 & 12.8 & 10.9 \\
\hline Net Power & MWe & 335.2 & 362.4 & 317.1 & 300.1 & 490.4 & 409.1 & 380.6 & 362.2 \\
\hline Heat Rate & $\mathrm{kJ} / \mathrm{kWh}$ & & & & & & & & \\
\hline Efficiency & $\%$ & $48.4 \%$ & $49.3 \%$ & $48.0 \%$ & $45.9 \%$ & $41.7 \%$ & $40.7 \%$ & $38.6 \%$ & $45.2 \%$ \\
\hline \multicolumn{10}{|l|}{ HTHE } \\
\hline Duty & $\mathrm{kJ} / \mathrm{h} \times 10^{6}$ & 224.5 & 224.5 & 224.5 & 224.5 & 609.0 & 609.0 & 609.0 & 459.9 \\
\hline Gas Flow & $\mathrm{kg} / \mathrm{h}$ & 61,989 & 377,342 & 450,180 & 484,704 & 742,508 & 883,690 & 948,831 & 684,666 \\
\hline
\end{tabular}


results indicate that injecting steam into the pyrolyzer does not have a significant beneficial impact on system performance.

As an aside, an additional run (Case 7) was made also assuming that the outlet temperature from the HTHE was increased to $1205^{\circ} \mathrm{C}\left(2200^{\circ} \mathrm{F}\right)$. However, for Case 7 the temperature from the primary air heater was increased from $760^{\circ} \mathrm{C}\left(1400^{\circ} \mathrm{F}\right)$ to $870^{\circ} \mathrm{C}\left(1600^{\circ} \mathrm{F}\right)$. This has two benefits: 1) it reduces the demands on the HTHE, thereby reducing the amount of fuel required, and 2) it provides a means to get more heat from the char into the gas turbine. As seen in Table 3 , this change provides a significant increase over Case 5 , but it still falls short of the performance estimated for Case 2 (the other two cases using the same steam injection ratio).

Based on Table 3, the bottom line is that there does not appear to be any significant benefit from increasing the temperature from the HTHE.

\section{Task 2 - Engineering Research and Development}

\section{Subtask 2.2 - Restrictive Pipe Discharge (RPD) System Cold Model}

The cold RPD tests have been completed. The results of these tests were reported in the JanuaryMarch 1996 Technical Progress Report [1]. Three particle size distributions (PSD's) were tested. The coarsest and the medium-size distributions performed well, but the flow with the finest PSD was somewhat erratic. The repercussions of these results are discussed further under Subtask 3.1.

\section{Task 3 - Subsystem Test Unit Design}

\section{Subtask 3.1 - Pyrolyzer/Char Transport Test Design}

\section{General Status}

A Design Review Meeting was held for the pyrolyzer/char transport test (PCTT). FWDC personnel and representatives from other Foster Wheeler units were present. The test plan and equipment design were presented. For the most part, the PCTT test plan and design were accepted with minor design changes. There were, however, two more significant changes to the plan. These changes involved the addition of another pyrolyzer arrangement and a change in the char depressurization system.

Some participants in the Design Review Meeting believed that it may be possible to use a bubbling bed arrangement for the pyrolyzer. Operationally this type of system would be simpler than a circulating bed because there would be no solids recirculation system. There are, however, some process concerns related to the HIPPS requirements. Because of the fine char size requirement, the bubbling bed will operate with a relatively short char residence time. This situation could cause uneven bed temperatures and fluctuations in the fuel gas conditions. Because of the possible benefits of bubbling bed operation, it was decided to test this arrangement in addition to the circulating bed tests. 
The pilot plant currently has a bubbling bed pyrolyzer, so tests can be run with a shorter lead time than the circulating bed tests. The plan is to make a few modifications to the existing plant and then test the bubbling bed pyrolyzer while we are waiting for delivery of the long-lead items for the circulating bed pyrolyzer. Modifications done prior to the bubbling bed tests will mainly be to the coal-feed system and the instrumentation. By using existing equipment, it is possible to do these tests without any new pressure vessels. Testing will then be done while we are waiting for the delivery of the vessels required for the circulating bed tests.

The other change to the PCTT plan is the design of the char depressurization system. It was originally planned to use a restrictive pipe discharge (RPD) system. Tests were run at the Institute of Gas Technology (IGT) to investigate the operation of this system with the char. Three PSD's were tested representing a range of possible char PSD's. The medium and coarse size distributions performed well in these tests, but the fine distribution (90 percent through 200 mesh) had erratic char flow. Although the required char PSD for the Foster Wheeler arch-fired combustion system will be determined in subsequent tests, these systems generally use relatively fine PSD's for low-volatile coal. It was therefore decided to proceed with a lock hopper system. If the combustion system tests indicate that a coarser PSD is possible, the use of an RPD can be reevaluated and added as a later improvement.

\section{Test Matrix}

The PCTT test matrix has been revised to include the bubbling bed tests. Also, the level of steam injection into the pyrolyzer has been included as a variable. Bechtel is finding that plant efficiency can be maximized with an optimal level of steam injection into the pyrolyzer. The steam injection can be used to shift the ratio of fuel gas to char and thereby optimize the topping and bottoming cycles.

The revised test matrix is shown in Table 4. To explore all possible combinations of the variables would result in an unreasonable number of test runs. The number of test runs has been reduced because of two factors. One factor is that a computer model will be developed concurrently with the pyrolyzer testing. The data from each test run will be used to benchmark and modify the computer model. This approach will require less test data than a completely empirical method. Also, some of the variables will become "go-no go" decisions, and once the decision is made, one variable is removed from the test matrix. For example, initial test runs will have set points with coarse sorbent and other set points with fine sorbent. With coarse sorbent, the goal is to remove as much spent sorbent from the bottom of the bed as possible. The fine sorbent approach is to let the sorbent go with the char and have a bed of sand. The most feasible approach will be chosen based on initial testing, and the other approach will be dropped from the test matrix.

\section{Data Acquisition}

The HIPPS pilot plant will be controlled by the same Fisher Provox DCS used for the SecondGeneration PFB test program. The original DCS system included a VAX/VMS-based data historian package which will be modified for the HIPPS program. This upgraded data archiving package will 
Table 4

Pyrolyzer Test Matrix

\begin{tabular}{|c|c|c|c|c|c|c|c|c|}
\hline $\begin{array}{l}\text { Run } \\
\text { No. }\end{array}$ & $\begin{array}{c}\text { Bed } \\
\text { Arrangement }\end{array}$ & $\begin{array}{l}\text { Coal } \\
\text { Size }\end{array}$ & $\begin{array}{l}\text { Sorbent } \\
\text { Size }\end{array}$ & Sand & $\begin{array}{l}\text { Steam Flow } \\
\quad(\mathrm{kg} / \mathrm{h})\end{array}$ & $\begin{array}{c}\text { Riser } \\
\text { Velocity } \\
(\mathbf{m} / \mathbf{s})\end{array}$ & $\begin{array}{l}\text { Cyclone } \\
\text { Design }\end{array}$ & Purpose \\
\hline 1 & Bubbling & $\begin{array}{l}\mathrm{C} 1 \\
\mathrm{C} 1 \\
\mathrm{C} 1 \\
\mathrm{C} 1 \\
\end{array}$ & $\begin{array}{l}\text { S1 } \\
\text { S1 } \\
\text { S2 } \\
\text { S2 } \\
\end{array}$ & $\begin{array}{l}\text { No } \\
\text { No } \\
\text { Yes } \\
\text { Yes } \\
\end{array}$ & $\begin{array}{l}24.4 \\
97.5 \\
24.4 \\
97.5 \\
\end{array}$ & $\begin{array}{l}0.95 \\
0.95 \\
0.95 \\
0.95\end{array}$ & $\begin{array}{l}-- \\
-- \\
-- \\
--\end{array}$ & $\begin{array}{l}\text { Obtain design data for bubbling bed opera- } \\
\text { tion with initial coal size. }\end{array}$ \\
\hline 2 & Bubbling & $\begin{array}{l}\mathrm{C} 2 \\
\mathrm{C} 2 \\
\mathrm{C} 2 \\
\mathrm{C} 2 \\
\end{array}$ & $\begin{array}{l}\text { S1 } \\
\text { S1 } \\
\text { S2 } \\
\text { S2 } \\
\end{array}$ & $\begin{array}{l}\text { No } \\
\text { No } \\
\text { Yes } \\
\text { Yes }\end{array}$ & $\begin{array}{l}24.4 \\
97.5 \\
24.4 \\
97.5 \\
\end{array}$ & $\begin{array}{l}0.95 \\
0.95 \\
0.95 \\
0.95 \\
\end{array}$ & $\begin{array}{l}-- \\
-- \\
-- \\
--\end{array}$ & $\begin{array}{l}\text { - Obtain design data for bubbling bed opera- } \\
\text { tion with second coal size. }\end{array}$ \\
\hline 3 & Circulating & $\begin{array}{l}\mathrm{C} 1 \\
\mathrm{C} 1 \\
\mathrm{C} 1 \\
\mathrm{C} 1 \\
\end{array}$ & $\begin{array}{l}\text { S1 } \\
\text { S1 } \\
\text { S2 } \\
\text { S2 } \\
\end{array}$ & $\begin{array}{l}\text { No } \\
\text { No } \\
\text { Yes } \\
\text { Yes } \\
\end{array}$ & $\begin{array}{l}24.4 \\
24.4 \\
24.4 \\
24.4 \\
\end{array}$ & $\begin{array}{l}1.52 \\
2.74 \\
1.52 \\
2.74 \\
\end{array}$ & $\begin{array}{l}\text { CY1 } \\
\text { CY1 } \\
\text { CY1 } \\
\text { CY1 } \\
\end{array}$ & $\begin{array}{l}\text { - Determine whether to design for sorbent car- } \\
\text { ryover or sorbent separation. } \\
\text { - Check initial coal size with circulating bed. }\end{array}$ \\
\hline 4 & Circulating & $\begin{array}{l}\mathrm{C} 3 \\
\mathrm{C} 3 \\
\mathrm{C} 3 \\
\mathrm{C} 3 \\
\mathrm{C} 3 \\
\mathrm{C} 3 \\
\end{array}$ & $\begin{array}{l}\text { TBD } \\
\text { TBD } \\
\text { TBD } \\
\text { TBD } \\
\text { TBD } \\
\text { TBD } \\
\end{array}$ & $\begin{array}{l}\text { TBD } \\
\text { TBD } \\
\text { TBD } \\
\text { TBD } \\
\text { TBD } \\
\text { TBD } \\
\end{array}$ & $\begin{array}{l}24.4 \\
24.4 \\
24.4 \\
97.5 \\
97.5 \\
97.5 \\
\end{array}$ & $\begin{array}{l}1.52 \\
2.74 \\
\text { TBD } \\
1.52 \\
2.74 \\
\text { TBD } \\
\end{array}$ & $\begin{array}{l}\text { CY1 } \\
\text { CY1 } \\
\text { CY1 } \\
\text { CY1 } \\
\text { CY1 } \\
\text { CY1 }\end{array}$ & $\begin{array}{l}\text { - Obtain design data for circulating bed with } \\
\text { initial cyclone design. }\end{array}$ \\
\hline 5 & Circulating & $\begin{array}{l}\text { TBD } \\
\text { TBD } \\
\text { TBD } \\
\text { TBD } \\
\end{array}$ & $\begin{array}{l}\text { TBD } \\
\text { TBD } \\
\text { TBD } \\
\text { TBD } \\
\end{array}$ & $\begin{array}{l}\text { TBD } \\
\text { TBD } \\
\text { TBD } \\
\text { TBD } \\
\end{array}$ & $\begin{array}{l}\text { TBD } \\
\text { TBD } \\
\text { TBD } \\
\text { TBD }\end{array}$ & $\begin{array}{l}1.52 \\
2.13 \\
2.74 \\
3.65 \\
\end{array}$ & $\begin{array}{l}\mathrm{CY} 2 \\
\mathrm{CY} 2 \\
\mathrm{CY} 2 \\
\mathrm{CY} 2 \\
\end{array}$ & $\begin{array}{l}\text { - Obtain design data for circulating bed with } \\
\text { second cyclone. }\end{array}$ \\
\hline 6 & Circulating & $\begin{array}{l}\text { TBD } \\
\text { TBD } \\
\text { TBD } \\
\text { TBD }\end{array}$ & $\begin{array}{l}\text { TBD } \\
\text { TBD } \\
\text { TBD } \\
\text { TBD }\end{array}$ & $\begin{array}{l}\text { TBD } \\
\text { TBD } \\
\text { TBD } \\
\text { TBD }\end{array}$ & $\begin{array}{l}\text { TBD } \\
\text { TBD } \\
\text { TBD } \\
\text { TBD }\end{array}$ & $\begin{array}{l}1.52 \\
2.13 \\
2.74 \\
3.65\end{array}$ & $\begin{array}{l}\text { TBD } \\
\text { TBD } \\
\text { TBD } \\
\text { TBD }\end{array}$ & - To obtain data as required. \\
\hline
\end{tabular}


be supported by a Unix-based HP Workstation acting as a main file server. The database will be accessible through a local-area network, and all of the client PC's will be outfitted with X emulation software. This data-archiving system will facilitate open data exchange between the Unix system and the PC's.

In an effort to address the scale-up issues of the pyrolyzer, a high-speed data-acquisition system will be installed to monitor differential pressure fluctuations along the riser. The data gathered from these high-speed transmitters $(100 \mathrm{~Hz})$ will be used to study the underlying hydrodynamic behavior of the pyrolyzer and to validate the modeling efforts being performed at M.I.T. The tests to be performed at M.I.T. utilize small-scale "cold" $\left(70^{\circ} \mathrm{F}\right.$., $\left.14.7 \mathrm{psia}\right)$ experimental models constructed of plexiglass to simulate "hot" $\left(1700^{\circ} \mathrm{F}\right.$., 200 psia) operating performance. A series of non-dimensional scaling parameters is matched between the cold model and the hot pilot plant to ensure hydrodynamic similitude.

An on-line mass spectrometer will be used during the Phase 2 HIPPS program to monitor the transient behavior of the pyrolyzer gas quality. The gas heating value and ammonia content are of particular concern to the gas turbine manufacturers, as these values affect power output and NOx emissions, respectively. The mass spectrometer affords an accurate measurement of each individual fuel gas component with a total sample response time of less than 5 seconds. The transient behavior of each fuel gas component will be monitored to determine the optimum air-staging requirements for the gas turbine.

\section{Pilot Plant Design}

The general circulating bed arrangement of the PCTT pilot plant is shown in Figures 6 and 7. The arrangement is basically the same as previously reported [2] except a lock hopper system replaces the RPD system. Bids on this equipment will be evaluated in July and a purchase order will be issued as soon as approval is received. Key features of the pilot plant design are the ability to vary the riser and cyclone inlet velocity and the ability to replace or modify the cyclone easily.

One change from previous operation of this pilot plant is the use of pulverized coal and sorbent. The current feed system uses separate trains consisting of a bucket elevator, silo, and Z-belt conveyor to transport the feedstocks up to the lock hoppers. Two aspects of these systems were in question: the ability to reliably feed the finer material and the safety requirements with the fine coal. Tests were run with the sorbent train feeding pulverized limestone. The material was pneumatically fed from a tank truck directly to the silo, bypassing the bucket elevator. The material was then transported up to the lock hoppers with the Z-belt conveyor and through the lock-hopper system. The system performed well, and it will be used essentially as is for the sorbent feeding.

In analyzing the coal feed system, it was determined that the changes that would be required for safe operation of the Z-belt conveyor would be fairly extensive. It was decided that it would be better to replace the Z-belt conveyor with a nitrogen-blown, dense-phase transport system which would be both safer and more reliable. Bid packages have been prepared for this equipment, and the purchase order will be placed in July. 


\section{Subtask 3.2 Char Combustion System Test Design}

The FWEC arch-fired combustion system is now the base case system for char combustion in HIPPS. The concept is illustrated in Figure 8. The lower furnace has two arches where the burners are located. The burners fire down into the furnace, and combustion air is added in stages through the front and rear walls. This type of arrangement causes a long flame path where the air supply is gradually added to the fuel to avoid quenching. This approach also results in essentially a staged combustion which tends to minimize NOx. In addition to the air staging, the geometry of the furnace promotes recirculation of hot gases from the upper furnace back into the flame. This situation is also a stabilizing influence on the flame and the flame temperature.

One difference between the HIPPS firing system and current arch-fired systems will be the burner itself. In conventional arch-fired systems, primary air is removed from the fuel stream by having a cyclone directly upstream of the point where the burner injects into the furnace. This helps to accomplish the air-staging effect. In the HIPPS system, the char will be transported by an inert gas, probably fuel gas. A part of the HIPPS char burner development will be to determine how best to add air at the burners.

Combustion tests will be run at the Foster Wheeler Combustion and Environmental Test Facility (CETF) in Dansville, New York. This facility is used to test burners. It consists of a furnace and convection pass that was designed to simulate conditions in larger scale boilers. Under HIPPS conditions, the facility will be capable of approximately $30 \mathrm{MM} \mathrm{Btu} / \mathrm{h}$ heat input to the burner. The furnace was originally built for arch firing, but it was later converted to horizontal firing. It will be converted back to arch firing with a design that will facilitate changing back and forth between the two configurations.

The CETF has fans, a pulverizer, and other auxiliary equipment required for a conventional combustion system. However, some additional equipment will be required to simulate the HIPPS conditions. A gas-fired duct heater and recirculation of flue gas will be used to obtain hot, reduced-oxygen-level combustion air.

The char combustion system tests will be run concurrently with the PCTT. Most of the tests will be run with commercially produced char, but char generated in the PCTT will also be used to the extent that it is available.

\section{Subtask 3.3 - Integrated System Test Design (IST)}

UTSI continued preliminary work to prepare for the IST. To help coordinate mechanical interfaces for the IST, packages of drawings of the coal-fired flow facility's (CFFF) mechanical systems were prepared for FWDC. Design details for the furnace, superheater and air heater, downstream pollution control equipment, and major support systems were provided. A Drafting Supervisor was assigned, initially to prepare drawing packages of the CFFF systems for FWDC. Using AutoCAD Release 12, the selected common software interface for drafting and mechanical design drawings, these packages 


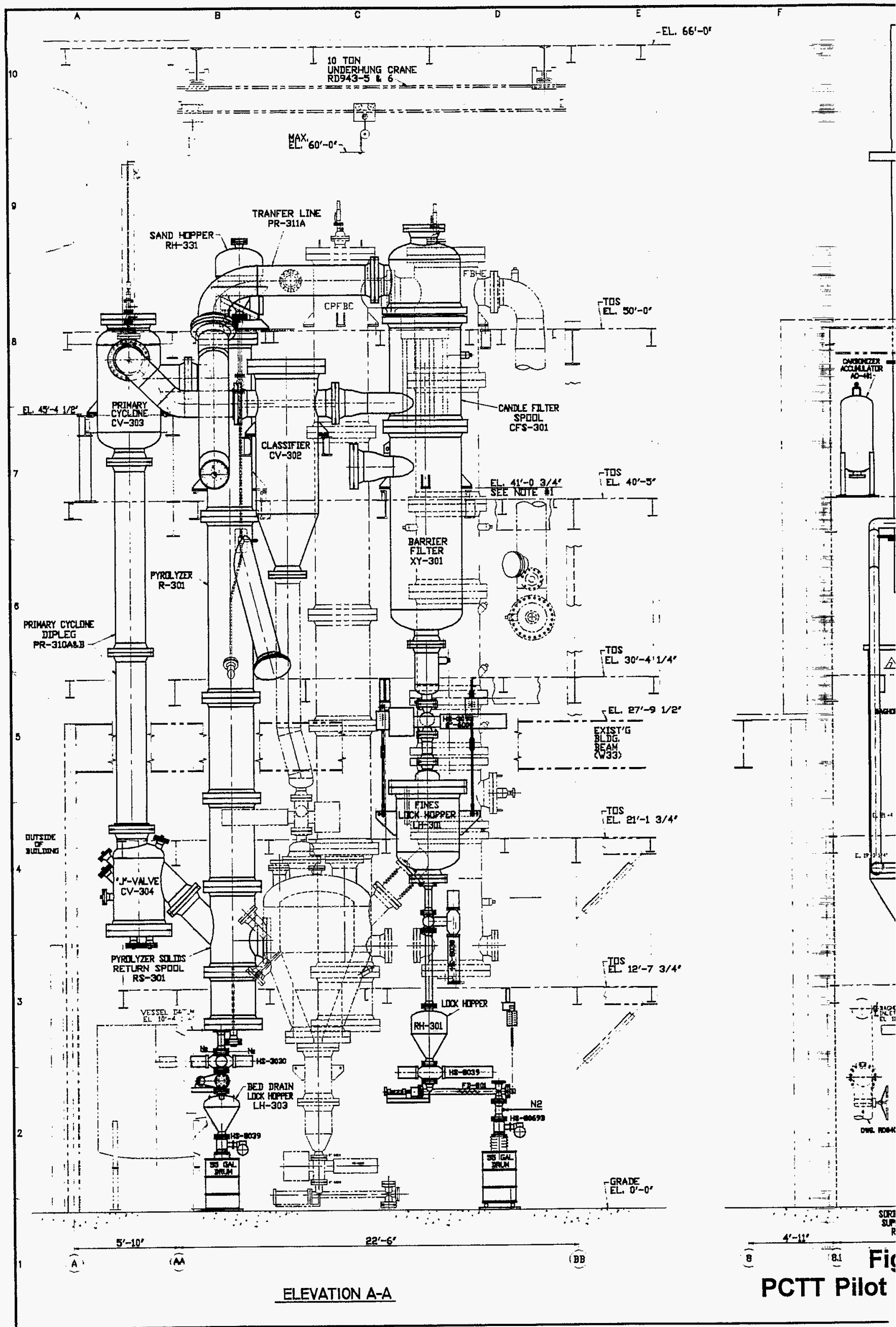




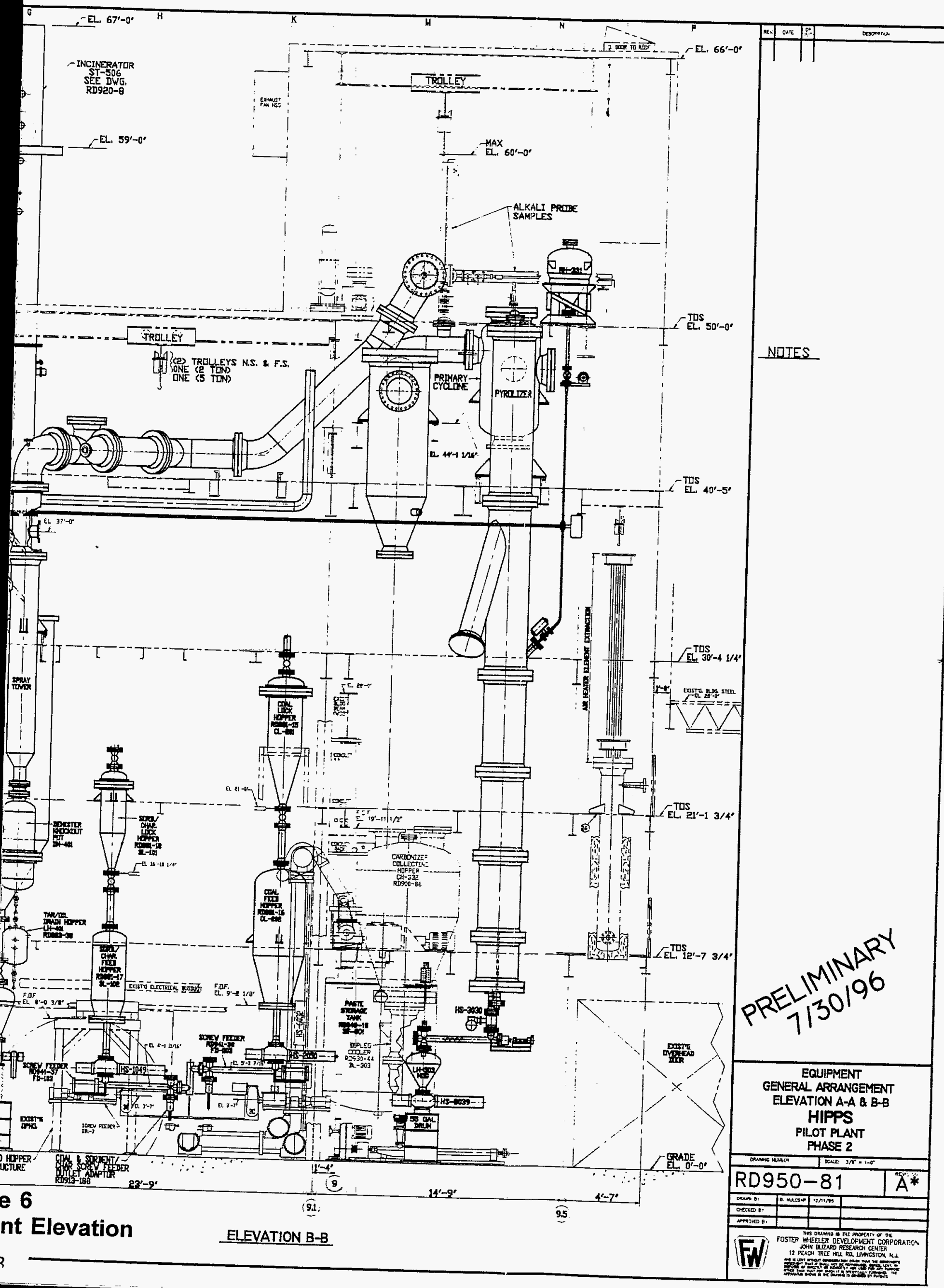




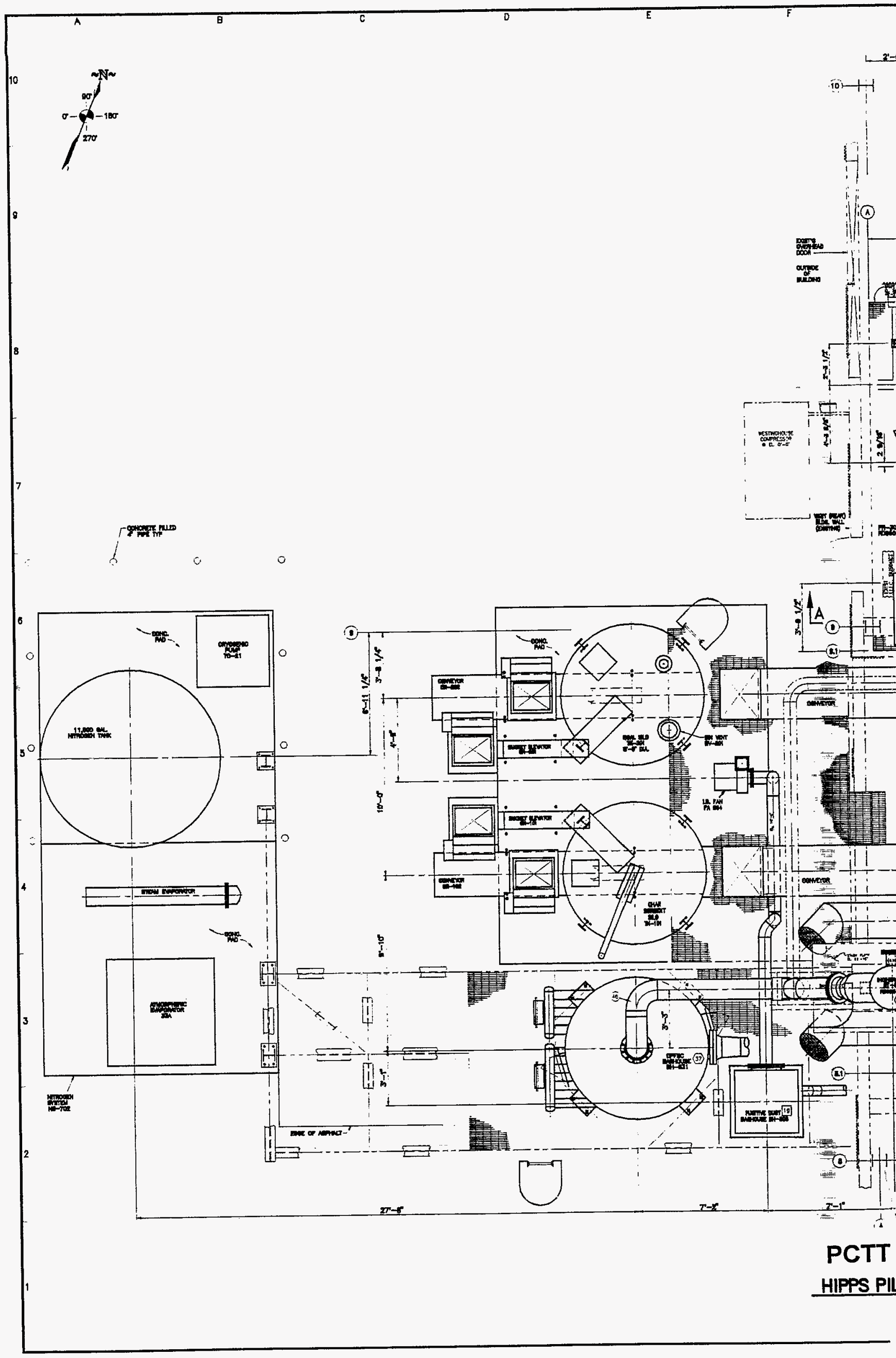




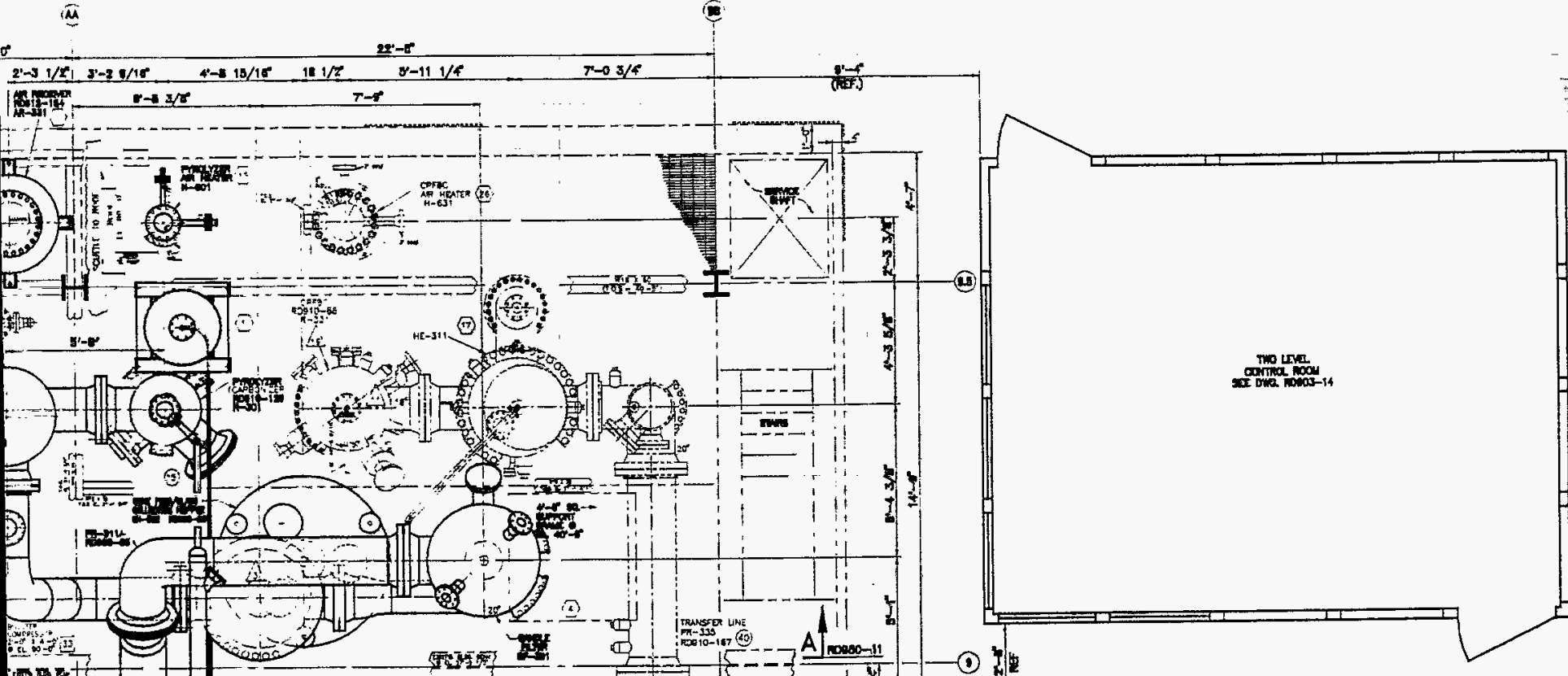
mont

$7+1-2=0$ than-
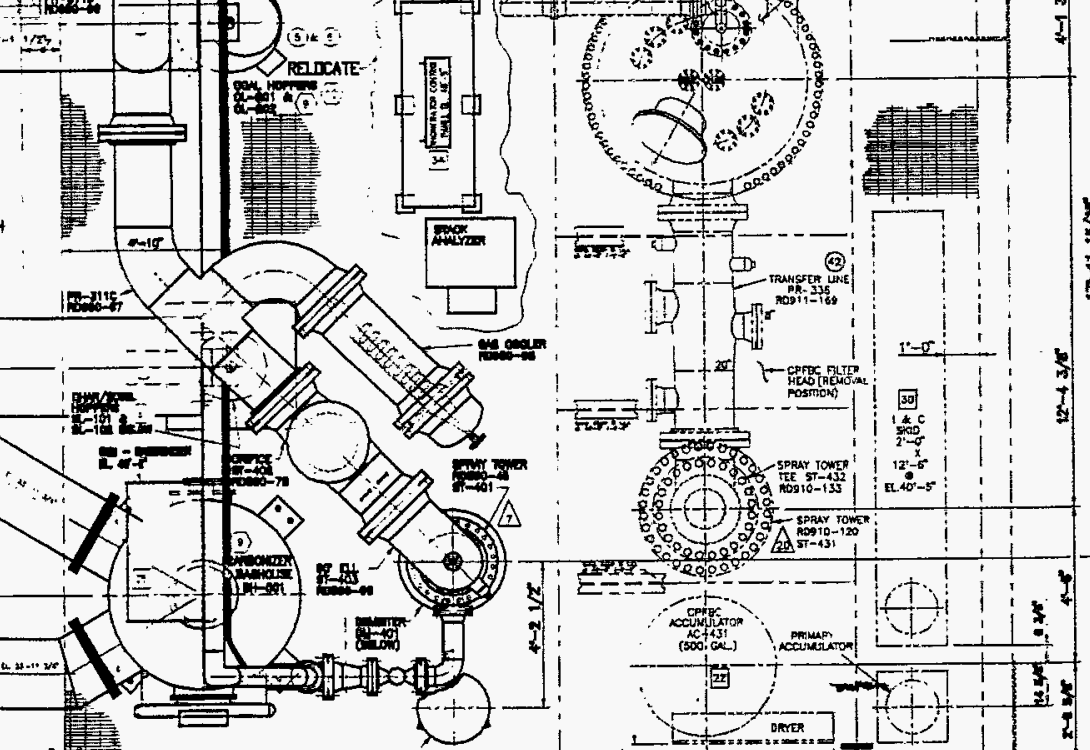

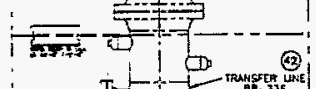

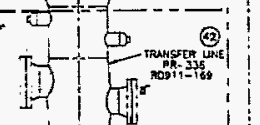

=- The

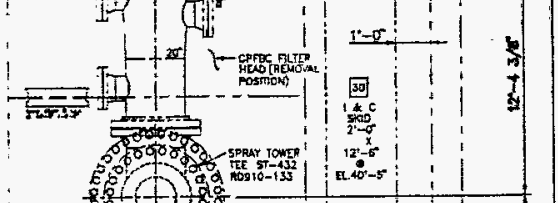

Fis,

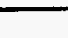




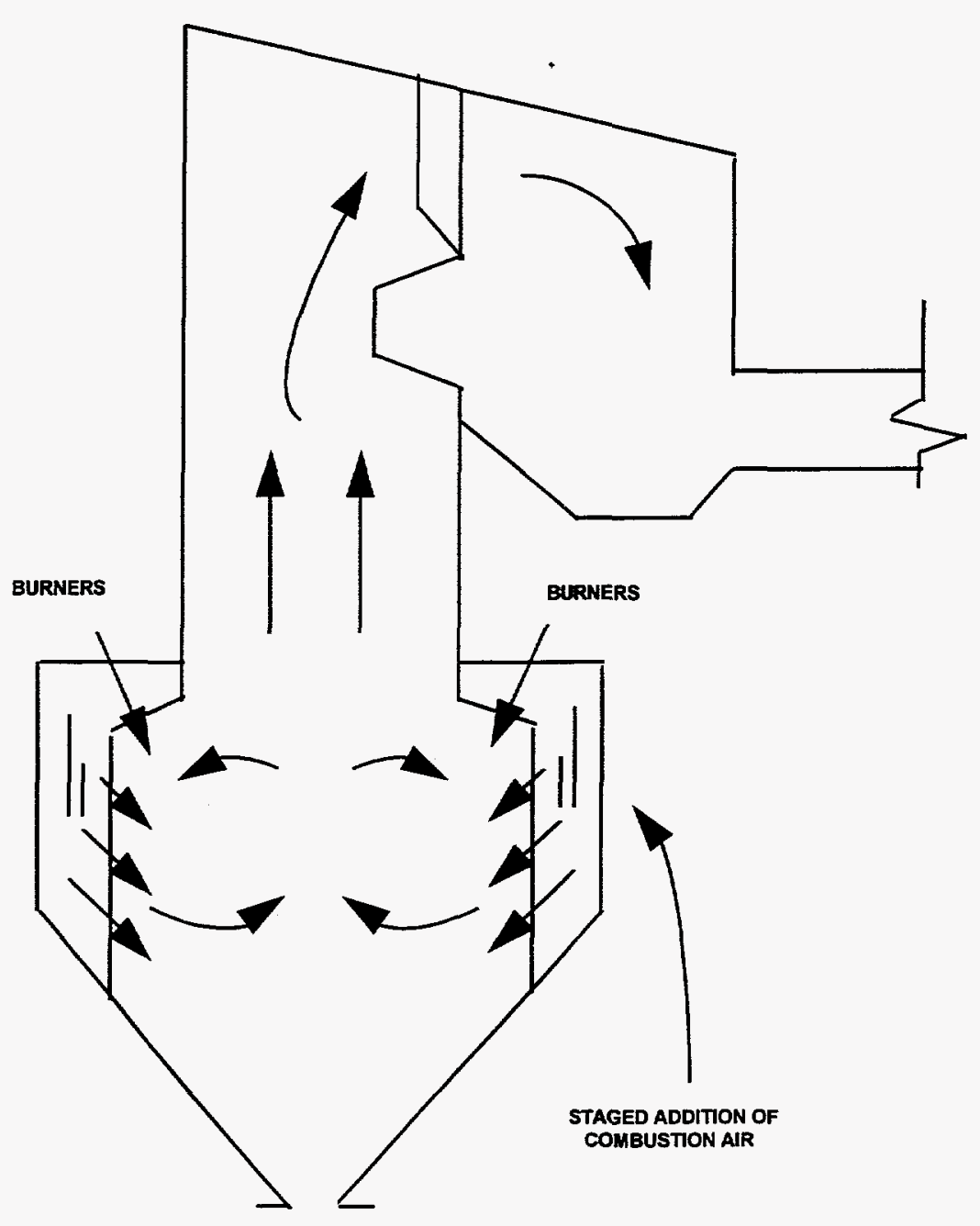

Figure 8 Arch Firing

will probably be provided on magnetic media. Bids were received and evaluated for job-shop drafting and design services, to assist in the IST design effort.

As part of the original plans to replace outmoded parts of the CFFF central data acquisition and control system with a distributed control system (DCS), specifications were completed, and competitive bids were requested. This DCS will be used both for coal processing in support of the PCTT and for the IST. To mitigate time as well as dollar costs of the IST, specifications require compatibility of the DCS with the Foster Wheeler control system being used for the PCTT. UTSI is coordinating acquisition of the DCS with FWDC to ensure that the system satisfies test and compatibility requirements.

A letter was received from the Tennessee Air Pollution Control Division stating that the IST test does indeed qualify under Title V of the CAAA as "conditional major", thus allowing the CFFF to be 
classified as a "pilot plant" and "insignificant emission unit". This places the CFFF in a categorically exempt status and allows testing to proceed with only limited air permit oversight and emissions monitoring. However, they are requiring updated permit applications to assure that the test does not significantly impact air quality. Regular emissions monitoring, although not continuous monitoring, will still be required.

UTSI is reviewing alternatives for supplying high-pressure steam to the pyrolyzer and feeding sorbent to the pyrolyzer. The CFFF's current steam capability is $1.03 \mathrm{MPa}$ (150 psig) steam, which is insufficient for pyrolyzer operation. Required steam pressure is expected to be about $1.38 \mathrm{MPa}$ (200 psig). Bids for both new and used boiler systems providing high-pressure steam for injection into the pyrolyzer during the IST were examined. Replacement of the CFFF low-pressure $5.89 \mathrm{MW}$ (600 bhp) boiler was also considered, as an alternate option. An existing location with appropriate foundation and building was identified, but these boilers would still require a preheat tank as well as utility installation. A decision will wait for completion of contract negotiations and continued availability of the used boilers, which seem the best option at present.

An investigation of the coal-feed system indicated a possible requirement for $2.07 \mathrm{MPa}$ ( 300 psia) driving pressure, well above the $1.38 \mathrm{MPa}(200 \mathrm{psi})$ available from the existing CFFF nitrogen system. Thus budgetary pricing was received for a new $\mathrm{N}_{2}$ booster compressor. The estimated cost for a new compressor and alternate costs to rebuild an existing unneeded CFFF air compressor to accommodate $\mathrm{N}_{2}$ are being compared.

Existing components of the CFFF coal-preparation system were reviewed for use in the HIPPS sorbent feed system and some components will be usable. Existing components of the UTSI Energy Conversion Facility coal system were also examined but found unsuitable for use in the sorbent-feed system because of pressure rating. Also, plans were initiated to examine the seed-injection system being excessed by a DOE facility in Montana in July. Preliminary indicates it may provide a satisfactory system.

\section{Task 4 -Subsystem Test Unit Construction}

The equipment-purchasing process has started for all three pilot plants.

\section{REFERENCES}

1. Foster Wheeler Development Corporation, "Engineering Development of Coal-Fired High Performance Power Systems- Technical Progress Report 2 (October through December 1995)", DOE PETC under contract DE-AC22-95PC95143, February 1996, pp 5-11.

2. Foster Wheeler Development Corporation, "Engineering Development of Coal-Fired High Performance Power Systems- Technical Progress Report 2 (October through December 1995)", DOE PETC under contract DE-AC22-95PC95143, February 1996, pp 18-30. 